\title{
Large-Scale Synoptic Systems and Fog During the C-FOG Field Experiment
}

\author{
Clive E. Dorman ${ }^{1,2}$ (D) Sebastian W. Hoch ${ }^{3}$. Ismail Gultepe ${ }^{4,5,6} \cdot$ Qing Wang ${ }^{7,8}$. \\ Ryan T. Yamaguchi ${ }^{7}$ · H. J. S. Fernando ${ }^{6} \cdot$ Raghavendra Krishnamurthy $^{6,9}$
}

Received: 24 April 2020 / Accepted: 18 June 2021 / Published online: 22 July 2021

(C) The Author(s) 2021

\begin{abstract}
The goal of this work is to summarize synoptic meteorological conditions during the Coastal Fog (C-FOG) field project that took place onshore and offshore of the Avalon Peninsula, Newfoundland, from 25 August until 8 October 2018. Visibility was measured at three locations at the Ferryland supersite that are about $1 \mathrm{~km}$ from each other, and at two additional sites 66 and $76 \mathrm{~km}$ to the north. Supporting meteorological measurements included surface winds, air temperature, humidity, pressure, radiation, cloud-base height, and atmospheric thermodynamic profiles from radiosonde soundings. Statistics are presented for surface measurements during fog events including turbulence kinetic energy, net longwave radiation, visibility, and precipitation. Eleven fog events are observed at Ferryland. Each significant fog event is related to a large-scale cyclonic system. The longest fog event is due to interaction of a northern deep low and a tropical cyclone. Fog occurrence is also examined across Atlantic Canada by including Sable Island, Yarmouth, Halifax, and Sydney. It is concluded that at Ferryland, all significant fog events occur under a cyclonic system while at Sable Island all significant fog events occur under both cyclonic and anticyclonic systems. The fog-formation mechanism involves cloud lowering and stratus broadening or only stratus broadening for the cyclonic systems while for the anticyclonic systems it is stratus broadening or radiation. Although widely cited as the main cause of fog in Atlantic Canada, advection fog is not found to be the primary or sole fog type in the events examined.
\end{abstract}

Keywords Atlantic Canada $\cdot$ Climatology $\cdot$ Coastal fog $\cdot$ Marine fog $\cdot$ Synoptic meteorology

\section{Introduction}

The study centres on Atlantic Canada, the site of the first organized marine fog investigation (Taylor 1917). With ship surface measurements and kite soundings, Taylor (1917) proposed the fundamental dynamics of marine fog. After a century, fog still has the attention

Clive E. Dorman

cdorman@ucsd.edu

Extended author information available on the last page of the article 
of sailors, even with radar and GPS navigation. We focus on fog formation in Atlantic Canada, which is driven by frequent variations in the synoptic-scale conditions and modified by local surface and boundary-layer conditions. The dynamics include eastward moving, upper level waves that are linked to sea-level cyclones and anticyclones (Bluestein 1993). A review of marine-fog investigations and the development in understanding fog over the past 100 years are given in Wang (1985), Lewis et al. (2004), Gultepe et al. (2007), Koračin et al. (2014), Koračin (2017) and Dorman et al. (2017). Byers (1959) describes 11 different fog types that are discussed by Gultepe et al. (2007). Those especially applicable to the focus area are: warm advection (air flows over colder water), cold air advection (air flows over warmer water), and radiation (surface or surface layer radiation-especially at night). Another process is cloud lowering, which Koračin et al. (2014) suggests should be reserved for the whole entity of cloud lowering, including the cloud top; (see Koračin et al. 2001). This process at times is confused with cloud broadening, defined as a cloud extending downward through the effect of precipitation evaporating and moistening the subcloud layer below the cloud base (Gultepe et al. 2007; Tardif and Rasmussen 2008; Dupont et al. 2012). Often, a fog occurrence has multiple causes and involves multiple processes.

During the summer, maximum fog occurrence is $45 \%$ over the Grand Banks of Newfoundland that is one of the world's two greatest marine-fog occurrences based on ship weather measurements (Dorman et al. 2017, 2019). During the fall, the fog-occurrence distribution is similar to that in the summer, but the maximum is reduced to $16 \%$. Around Ferryland on the eastern coast of Newfoundland's Avalon Peninsula, the autumn fog occurrence based on ship measurement is about 8\%. In comparison with Atlantic Canada airport stations (Wang 2006), Dorman et al. (2017) found that summer ship-fog occurrence values tended to be similar to land values, while winter values were an order of magnitude lower. The September occurrence values range between those of summer and winter.

St John's airport is the only full meteorological surface station on the Avalon Peninsula. Diurnally, the maximum fog frequency occurs around sunrise for all year. The fog maximum occurs in May at sunrise $(\approx 22 \%)$. In September, the fog occurrence is reduced to $\approx 10 \%$ at sunrise (Gultepe et al. 2007). However, St John's airport is $134 \mathrm{~m}$ above sea level (a.s.l.), so that fog there is often part of a stratus cloud that does not extend down to sea level.

Our goal is to evaluate the relationship between coastal-fog occurrence and the synoptic-scale weather system activity over Atlantic Canada. Coastal-fog occurrence is assessed with respect to the dynamics of synoptic-scale systems during the autumn of 2018 and local weather conditions that occurred at the C-FOG project sites located along the Avalon Peninsula, Newfoundland, Nova Scotia, and Sable Island. Section 2 summarizes the C-FOG field project, its measurements, and the analysis used. Section 3 is for the results, and Sect. 4 is for discussions which includes the causes of fog. Conclusions are given in Sect. 5.

\section{Measurements, Field Project, and Analysis}

The main field site, Ferryland, is located on the eastern central coast of the Avalon Peninsula which is a small peninsula adjacent to the south-east tip of Newfoundland (Fig. 1). In this setting, the central Avalon Peninsula is exposed to westerly winds from the ocean. The C-FOG field project lasted from 25 August to 8 October 2018. A full overview of C-FOG, including the observation sites and instrumentation, is given in Fernando et al. (2021). Ferryland contained three sites with visibility measurements using Vaisala PWD22 or PWD52 present weather detectors (Gultepe et al. 2021). These are the Battery site at $2 \mathrm{~m}$ a.s.l. next 
Fig. 1 The C-FOG Ferryland supersite on the eastern coast of the Avalon Peninsula consists of the instrumented sites Battery (B), The Downs (D), and Judges' Hill (J) (a). C-FOG sites on the eastern Avalon Peninsula (AP) besides Ferryland $(\mathrm{F})$ were Blackhead (L) and Flatrock (F). Also on the AP was the Mt. Pearl RAOB station (M) and St John's Airport (S) (b). Other surface stations with visibility measurements are Sydney $(\mathrm{N})$ and Halifax $(\mathrm{H})$, and those with a nearby RAOB station facing the open Atlantic are Yarmouth (Y) and Sable Island (I) (c). See Table 1 for station details

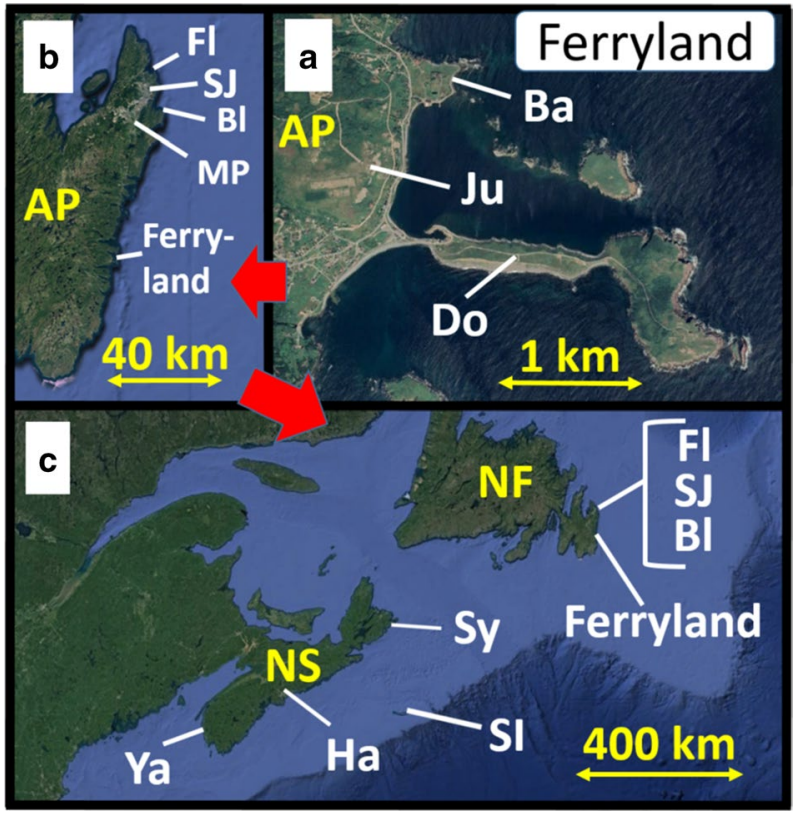

to the beach (Table 1), the Downs site at $32 \mathrm{~m}$ a.s.l. located on a narrow, eastward extending peninsula surrounded by the sea, and Judges' Hill, the most western and most elevated site (95 m a.s.1.) on top of a low hill. All three sites were within about one $\mathrm{km}$ of each other. Both the Battery and Downs sites were further instrumented with 15-m meteorological flux towers including multiple levels of temperature, relative humidity, and wind sensors, and Vaisala CL31 ceilometers. Ceilometers can be used to detect fog (Gultepe et al. 2009; Dabas et al. 2012; Arun et al. 2018) and these confirmed the Ferryland fog events primarily detected with the present weather and visibility measurements. The same instruments were also deployed at the Blackhead and Flatrock sites, 59 and $77 \mathrm{~km}$ north of Ferryland (Fig. 1). Additional observations were from Mt. Pearl, a RAdiosonde OBservation program (RAOB) upper air station, and St. John's airport, both on an elevated plateau (Table 1, Fig. 1b).

Along with the Avalon Peninsula stations, four additional airport stations, some with RAOB soundings, will be used to investigate broader details of fog across the extent of Atlantic Canada facing the open ocean (Table 1). One is Sable Island, representing the open ocean conditions over an outer shelf (Fig. 1). Sable Island is a low sand island extending in a $43-\mathrm{km}$-long crescent shape and $1.2 \mathrm{~km}$ at its widest. The small size, scant elevation, and great distance away from Nova Scotia ensures minimal land influence on observations.

On south-western Nova Scotia is the Yarmouth airport at $43 \mathrm{~m}$ a.s.l. on a low coastal plain and $5.4 \mathrm{~km}$ from the open ocean. The nearby Yarmouth sounding station is at $9 \mathrm{~m}$ a.s.l. Other Nova Scotian station data used herein are from Halifax and Sydney airports which are higher and further inland than Yarmouth.

In the analysis, surface-based measurements at C-FOG sites and airports are used to describe fog occurrence. Lower atmospheric conditions are established through RAOB and C-FOG radiosonde observations. This integrated data are used to assess fog interaction with synoptic meteorological conditions using the North American Regional Reanalysis 
Table 1 Stations with elevation, distance to the Battery site, and number of fog events and fog hours during September 2018

\begin{tabular}{|c|c|c|c|c|c|c|c|}
\hline Station & Symbol & Type & Ht a.s.l. (m) & $\begin{array}{l}\text { Distance } \\
\text { to battery } \\
(\mathrm{km})\end{array}$ & \# Fog events & \# Fog hours & $\begin{array}{l}\% \text { Sept fog } \\
\text { occur. [hrs] }\end{array}$ \\
\hline \multicolumn{8}{|c|}{ Avalon Peninsula } \\
\hline Battery & B & Field & 6 & 0 & 6 & 31 & 4.3 \\
\hline The Downs & $\mathrm{D}$ & Field & 32 & 1.4 & 6 & 41 & 5.7 \\
\hline Judges’ Hill & $\mathrm{J}$ & Field & 95 & 0.8 & 13 & 73 & 10.1 \\
\hline Mt Pearl & M & RAOB & 133 & 54 & - & - & - \\
\hline Blackhead & $\mathrm{L}$ & Field & 10 & 59 & 7 & 13 & 1.8 \\
\hline St Johns' & $\mathrm{S}$ & Air & 134 & 66 & 11 & 55 & 7.6 \\
\hline Flatrock & $\mathrm{F}$ & Field & 7 & 77 & 5 & 9 & 1.2 \\
\hline \multicolumn{8}{|l|}{ Nova Scotia } \\
\hline Sydney & $\mathrm{N}$ & Air & 56 & 563 & 3 & $8 *$ & 1.1 \\
\hline Halifax & $\mathrm{H}$ & Air & 145 & 864 & 7 & $26^{*}$ & 3.6 \\
\hline Yarmouth & $\mathrm{Y}$ & Air & 43 & 1088 & 10 & $44^{*}$ & 6.1 \\
\hline Yarmouth & $\mathrm{Y}$ & RAOB & 9 & - & - & - & - \\
\hline \multicolumn{8}{|l|}{ Sable Island } \\
\hline Sable & I & Air & 4 & 660 & 6 & $22 *$ & 3.1 \\
\hline Sable & I & RAOB & 5 & - & - & - & - \\
\hline
\end{tabular}

"Field" are C-FOG surface meteorological stations with a visibility measurement; "Air" are airport surface stations; * =observation gaps less than $10 \%$ of record

(NARR) and satellite observations. In the end, these local fog assessments are evaluated using climatological analysis of long-term observations.

\section{Results}

In this section, a climatology of local weather stations is performed, followed by a weather summary at Ferryland. After this, case studies will be presented for Newfoundland and Sable Island.

\subsection{Climatology}

The climate setting for the month of September was examined with the NARR 20-year mean climatology based on 32-km grid-point separation (https://psl.noaa.gov/cgi-bin/data/ narr/plothour.pl. Mesinger et al. 2006). In September, Newfoundland lies under a steep climatological zonal gradient from sea level to $500 \mathrm{hPa}$ between the North Atlantic Subtropical Anticyclone at $30^{\circ} \mathrm{N}$ and a polar low at $80^{\circ} \mathrm{N}$ (Fig. 2).

The 500 and $700 \mathrm{hPa}$ geopotential height (GPH) analyses (latter not shown) are very similar in details. Both have an open anticyclonic zone along $30^{\circ} \mathrm{N}$ and a cyclone centred on the north-west side of Greenland. At $850 \mathrm{hPa}$ GPH (not shown) and above, dense isoheights are oriented west-east over Newfoundland and eastern Canada.

The sea-level pressure (SLP) analysis in the south of the domain is dominated by the North Atlantic Subtropical Anticyclone with a centre near $35^{\circ} \mathrm{N} 39^{\circ} \mathrm{W}$. Far to the 


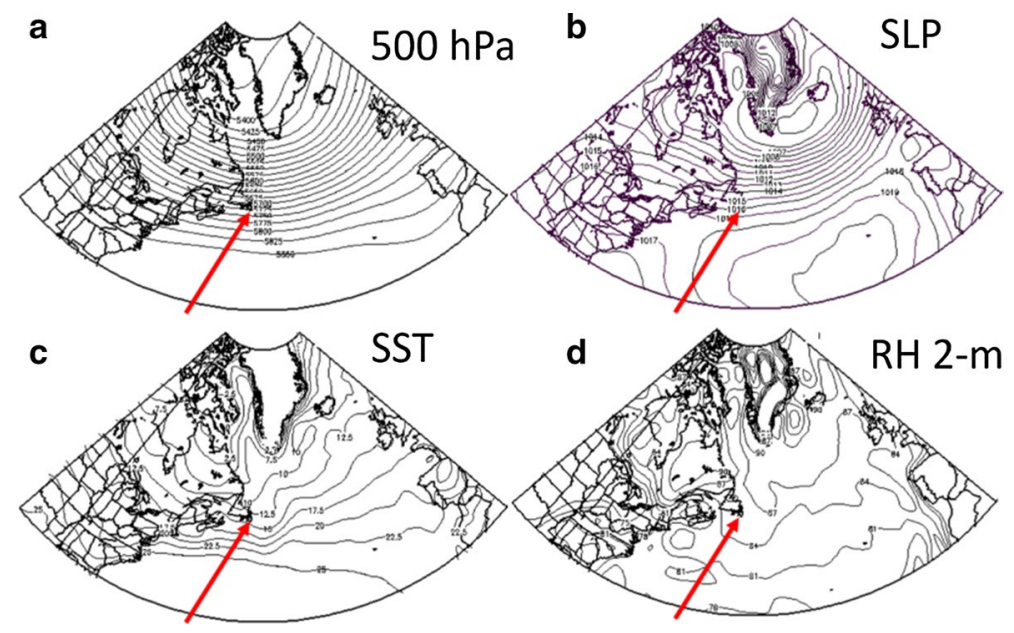

Fig. 2 NARR mean September 1999-2018 of the 500 hPa height contours, SLP, SST, and relative humidity at $2 \mathrm{~m}$. Images provided by the NOAA/ESRL Physical Sciences Division, Boulder, Colorado from http:// www.esrl.noaa.gov/psd/.

north, two low pressure systems are located over the Labrador Sea and between southern Greenland and Iceland. Closely packed west-east-oriented isobars cover Newfoundland and eastern Canada. Sea level climatological winds over Newfoundland are from west to west-south-west.

The sea-surface temperature (SST), the anchor on the bottom of the atmospheric sector over water, is asymmetrical, reflecting the role of the clockwise North Atlantic gyre with the warm, eastward Gulf Stream brushing along the North America shelf edge (Tomczak and Godfrey 2020). This is associated with densely packed isotherms starting at Cape Hatteras $\left(35^{\circ} \mathrm{N}\right)$ and extending to the north-east. In contrast, a cold Labrador Current moves southward along eastern Canada, past Newfoundland where it comes in contact with the Gulf Stream.

The climatological NARR 2-m relative humidity $(R H)$ is closely related to fog. Nearsurface air masses above the warm Gulf Stream are influenced by the western side of the North Atlantic anticyclone and thus advected from the south-west towards Newfoundland. On the south-east tip of Newfoundland, the climatological 2-m relative humidity reaches $86 \%$ which is elevated compared to humidities further south but below the threshold for fog $(>90 \%)$ which will be discussed later in this paper.

In the summer, cyclones most frequently travel across Quebec and northern Newfoundland before moving over the Atlantic. A less frequent path is along the east coast of the U.S. and Canada. Anticyclones tend to be concentrated in the summer along eastern Canada and the adjacent Atlantic (Palmén 1969; Reitan 1974; Zishka and Smith 1980). Anticyclones tend to form in the north-east U.S. and move eastward along Atlantic Canada over water but avoid Newfoundland.

In the winter, cyclone paths are much farther south in the interior of North America and along the coast of eastern North America. However, both paths join over water north-east of Newfoundland. In September, the path of cyclones and anticyclones is between that of summer and winter. 
Table 2 September 2018 Ferryland Fog events by hour

\begin{tabular}{|c|c|c|c|c|c|c|c|c|c|c|c|c|c|c|c|c|c|c|c|c|c|c|c|c|}
\hline $\begin{array}{l}\mathrm{DY} \\
/ \mathrm{H}\end{array}$ & 0 & 1 & 2 & 3 & 4 & 5 & 6 & 7 & 8 & 9 & 1 & 1 & 1 & & $\begin{array}{l}1 \\
4\end{array}$ & $\begin{array}{l}1 \\
5\end{array}$ & $\begin{array}{l}1 \\
6\end{array}$ & $\begin{array}{l}1 \\
7\end{array}$ & $\begin{array}{l}1 \\
8\end{array}$ & & & $\begin{array}{l}2 \\
1\end{array}$ & & \begin{tabular}{|l|}
2 \\
3 \\
\end{tabular} \\
\hline 02 & & & & & & & & & & & & & & & & & & & & & & & & \\
\hline 03 & & & & & & & & & & & & & & & & & & & & & & & & \\
\hline 04 & & & & & & & & & & & & & & & & & & & & & & & & \\
\hline 08 & & & & & & & & & $\mathrm{~J}$ & $\mathrm{~J}$ & J & $\begin{array}{l}J \\
D\end{array}$ & & & & & & & & & & & & \\
\hline 12 & & & & & & & & & & & & & & & & J & $\mathrm{J}$ & J & J & J & & & & \\
\hline 13 & & & & & & & & & & & & & & & & . & . & & . & J & & & & $\mathrm{J}$ \\
\hline 14 & $\begin{array}{l}\text { J } \\
\text { D }\end{array}$ & $\begin{array}{l}\mathrm{J} \\
\mathrm{D}\end{array}$ & $\begin{array}{l}\mathrm{J} \\
\mathrm{D}\end{array}$ & $\begin{array}{l}\mathrm{J} \\
\mathrm{D}\end{array}$ & $\begin{array}{l}\mathrm{J} \\
\mathrm{D}\end{array}$ & & & & & & & & & & & & & & & & & & & \\
\hline 15 & & & & $\mathrm{~J}$ & $\mathrm{~J}$ & & & & & & & & & & & & & & & & & & & \\
\hline 16 & & & & & & & & & & & & & & J & J & J & $\begin{array}{l}\mathrm{J} \\
\mathrm{D}\end{array}$ & $\mathrm{J}$ & J & J & J & & & \\
\hline 17 & & & & & & & & & & & J & J & J & & & & & & & & & & & \\
\hline 27 & & & & & & & & & & & & & & & & & . & & & & & & & \\
\hline 28 & & $\mathrm{~J}$ & $\mathrm{~J}$ & & $\begin{array}{l}\mathrm{J} \\
\mathrm{B}\end{array}$ & 3 & $J$ & & & & & & & $J$ & & J & $\mathrm{J}$ & $\begin{array}{l}J \\
D\end{array}$ & 3 & & J & & & $\begin{array}{l}\mathrm{J} \\
\mathrm{B}\end{array}$ \\
\hline 29 & 3 & 3 & 3 & 3 & 3 & 3 & 3 & 3 & 3 & 3 & 3 & 3 & 3 & 3 & 3 & 3 & 3 & $\begin{array}{l}\mathrm{J} \\
\mathrm{D}\end{array}$ & $\begin{array}{l}\mathrm{J} \\
\mathrm{D}\end{array}$ & 3 & & $\begin{array}{l}J \\
D\end{array}$ & & \\
\hline 30 & 3 & 3 & $\begin{array}{l}\mathrm{J} \\
\mathrm{D}\end{array}$ & $\mathrm{D}$ & $\begin{array}{l}\mathrm{B} \\
\mathrm{D}\end{array}$ & 3 & & & & J & & & & & & & & & & & & & & \\
\hline
\end{tabular}

Fog is shown for a station if fog occurs during more than $6 \%$ of observations taken during that hour. The hour of day in UTC is shaded in the top row and bold denotes near sunrise (0900 UTC) and near sunset (1900 UTC). Left column is the day of September 2018 with Atlantic fog-free days not included. J= Judge's Hill, $\mathrm{D}=$ The Downs, $\mathrm{B}=$ Battery, $3=$ all 3 . Colour indicates fog occurring at a single station or combinations of stations: Blue $=\mathrm{J}$, light blue $=\mathrm{J} \& \mathrm{~B}$, light green $=\mathrm{J} \& \mathrm{D}$, pink $=\mathrm{B} \& \mathrm{D}$, olive $=\mathrm{D}$, orange $=\mathrm{B}$, dark green $=$ all 3 stations

\subsection{Newfoundland Fog Case Studies}

\subsubsection{Overview of All Ferryland Cases}

As noted in Sect. 2, fog was detected by the visibility being less than $1 \mathrm{~km}$ at one or more of three Ferryland visibility instruments whose data were digitized into 1-min intervals. Before the visibility instruments were operational (8 September 2018), fog presence was detected by three additional sources. One was when the ceilometer maximum backscatter base was $<100 \mathrm{~m}$ (Arun et al. 2018). The second was by radiometer measurements as the presence of fog reduces the expected inbound solar radiation during the day and increases the downward infrared radiation at night (Gultepe et al. 2009). The third was with automated cameras. Fog is presented as occurring in hourly units at a station in Table 2, where fog is shown if fog occurred more than $6 \%$ of that hour. This was found to be the minimum length of what was supported by other measurements and excluded anomalous spikes. Use of fog-hours was helpful for dealing with short-term visibility fluctuating between less than and greater than $1 \mathrm{~km}$ over periods of minutes to a few tens of minutes. Fog occurred 
at Judges' Hill for all September fog-hours either by itself or with others for all but $3 \mathrm{~h}$ (Table 2). Fog at all three stations occurred for $25 \mathrm{~h}$ and included the longest event, which lasted from 2200 UTC 28 September through 0500 UTC 30 September. A Ferryland fog event was defined as a period of fog-hours when fog occurred at any station or combinations of stations without breaks.

To test the possible role of advection in generating the Ferryland fog events, back trajectories were generated with the Hybrid Single-Particle Lagrangian Integrated Trajectory model (HYSPLIT) analysis (Stein et al. 2015; Rolph et al. 2017). These trajectories were created with the HYSPLIT ${ }^{1}$ model, which utilized NARR to compute the path that a 2-m air parcel above the ground at Judges' Hill would take if moving backwards for $24 \mathrm{~h}$. In addition to 2-m back trajectories, trajectories were also run for $300 \mathrm{~m}$ and $600 \mathrm{~m}$ (not shown), which produced similar results but from a more distant starting point. The results shown in Table 3 are for the radial direction (clockwise) and straight-line distance from Judges' Hill to the point where the parcel originated 24-h earlier. Symbol "F" indicates that fog occurred during that hour. An asterisk indicates a significantly curved, cyclonic path in the last portion of the trajectory that reversed the parcel direction. The central column is the back trajectory at the start hour of the fog event and at the start of the last hour of the event. The last hour was left blank if the event only occurred during one hour. To further examine any possible near event shifts, the Judges' Hill back trajectories are given $6 \mathrm{~h}$ and $3 \mathrm{~h}$ before the fog event and $3 \mathrm{~h}$ and $6 \mathrm{~h}$ after the last hour of the fog event.

The advection type was determined using a long-term averaged SST for field September which is constructed from the NOAA OI SST V2 High Resolution data ${ }^{2}$ provided by the NOAA/OAR/ESRL PSL, Boulder, Colorado, USA (Reynolds et al. 2002). The SST isotherms offshore from Judges' Hill were oriented along $280^{\circ}-100^{\circ}$ direction. Neutral surface advection was oriented within $\pm 20^{\circ}$ of this SST isotherm alignment. Warm air advection was from $120-180-260^{\circ}$.

For the start hour of the 12 fog events, back-trajectory warm-air advection occurred seven times resulting in fog, neutral air advection occurred three times, and cold air advection occurred two times. In spite of the warm air advection, it will be shown later that fog did not occur until a cyclonic structure was directly overhead. It is also of note that in the back-trajectory analyses for 3 and $6 \mathrm{~h}$ before and after the event, there were 28 cases of warm air advection events over cold water, 22 of them (pink colour) did not result in fog. There were many more of the latter cases occurring during the remainder of September not shown here. The overwhelming conclusion is that warm air advection does occur frequently but, for the bulk of cases, does not result in a fog event. Advection is not a controlling factor for fog at Ferryland. It will be shown that a cyclonic feature crossing overhead is the triggering factor that controls Ferryland fog formation.

The 12 Ferryland September fog events are now examined for their characteristics (Table 4). The Downs soundings during or within $1 \mathrm{~h}$ of a fog event were examined for a stable layer capping a surface layer which has been cited a significant factor in for formation (Gultepe et al. 2007; Tardif and Rasmussen 2008; Dupont et al. 2012). The stable layer was a weak temperature inversion or an isothermal layer (both highlighted by pink in the table) and with a dry layer. There were also 2 cases of a fog layer capped by a dry layer but not an inversion (highlighted by yellow). A white box indicated a sounding within $4 \mathrm{~h}$ of the fog while a dash indicated that no sounding was available. A stable layer capping the

\footnotetext{
${ }^{1}$ https://www.ready.noaa.gov/HYSPLIT_traj.php.

${ }^{2}$ https://psl.noaa.gov/data/gridded/data.noaa.oisst.v2.highres.html.
} 
Table 3 Results from the HYSPLIT 24-h back trajectories for 2-m level at Judges' Hill for the September 2018 Ferryland fog events

\begin{tabular}{|c|c|c|c|c|c|c|c|c|}
\hline Ev & $\begin{array}{l}\text { Date } \\
\text { Fog } \\
\text { start } \\
\text { day/ } \\
\text { hour }\end{array}$ & $\begin{array}{l}\text { Date } \\
\text { Fog } \\
\text { end } \\
\text { day/ } \\
\text { hour }\end{array}$ & $\begin{array}{l}\text { 6hrs } \\
\text { Before } \\
\text { dir/ } \\
\text { dist }\end{array}$ & $\begin{array}{l}\text { 3hrs } \\
\text { Before } \\
\text { dir/ } \\
\text { dist }\end{array}$ & $\begin{array}{l}\text { Fog Ev } \\
\text { Start Hr } \\
\text { dir/ } \\
\text { dist }\end{array}$ & $\begin{array}{l}\text { Fog Ev } \\
\text { Last Hr } \\
\text { dir/ } \\
\text { dist }\end{array}$ & $\begin{array}{l}\text { 3hrs } \\
\text { After } \\
\text { dir/ } \\
\text { dist }\end{array}$ & $\begin{array}{l}\text { 6hrs } \\
\text { After } \\
\text { dir/ } \\
\text { dist }\end{array}$ \\
\hline 1 & 08/08 & $08 / 12$ & $\begin{array}{l}290^{\circ} \\
345 \mathrm{~km}\end{array}$ & $\begin{array}{l}285^{\circ} \\
370 \mathrm{~km}\end{array}$ & $\begin{array}{l}280^{\circ} \mathrm{F} \\
375 \mathrm{~km}\end{array}$ & $\begin{array}{l}277^{\circ} \mathrm{F} \\
380 \mathrm{~km}\end{array}$ & $\begin{array}{l}275^{\circ} \\
405 \mathrm{~km}\end{array}$ & $\begin{array}{l}270^{\circ} \\
430 \mathrm{~km}\end{array}$ \\
\hline 2 & $12 / 15$ & $12 / 20$ & $\begin{array}{l}235^{\circ} \\
240 \mathrm{~km}\end{array}$ & $\begin{array}{l}210^{\circ} \\
260 \mathrm{~km}\end{array}$ & $\begin{array}{l}175^{\circ} \mathrm{F} \\
420 \mathrm{~km}\end{array}$ & $\begin{array}{l}170^{\circ} \mathrm{F} \\
340 \mathrm{~km}\end{array}$ & $\begin{array}{l}180^{\circ} \\
600 \mathrm{~km}\end{array}$ & $\begin{array}{l}180^{\circ} \\
610 \mathrm{~km}\end{array}$ \\
\hline 3 & $13 / 19$ & $13 / 20$ & $\begin{array}{l}165^{\circ} \\
290 \mathrm{~km}\end{array}$ & $\begin{array}{l}140^{\circ} \\
240 \mathrm{~km}\end{array}$ & $\begin{array}{l}100^{\circ} \mathrm{F} \\
160 \mathrm{~km}\end{array}$ & & $\begin{array}{l}085^{\circ} * \mathrm{~F} \\
170 \mathrm{~km}\end{array}$ & $\begin{array}{l}050^{\circ} \mathrm{F} \\
175 \mathrm{~km}\end{array}$ \\
\hline 4 & $13 / 22$ & $14 / 05$ & $\begin{array}{l}140^{\circ *} \\
240 \mathrm{~km}\end{array}$ & $\begin{array}{l}100^{\circ} * \mathrm{~F} \\
160 \mathrm{~km}\end{array}$ & $\begin{array}{l}085^{\circ} * \mathrm{~F} \\
170 \mathrm{~km}\end{array}$ & $\begin{array}{l}005^{\circ} \mathrm{F} \\
250 \mathrm{~km}\end{array}$ & $\begin{array}{l}335^{\circ} \\
310 \mathrm{~km}\end{array}$ & $\begin{array}{l}315^{\circ} * \\
520 \mathrm{~km}\end{array}$ \\
\hline 5 & $15 / 03$ & $15 / 05$ & $\begin{array}{l}004^{\circ} \\
400 \mathrm{~km}\end{array}$ & $\begin{array}{l}008^{\circ} \\
385 \mathrm{~km}\end{array}$ & $\begin{array}{l}010^{\circ} \mathrm{F} \\
440 \mathrm{~km}\end{array}$ & $\begin{array}{l}010^{\circ} \mathrm{F} \\
300 \mathrm{~km}\end{array}$ & $\begin{array}{l}325^{\circ} \\
180 \mathrm{~km}\end{array}$ & $\begin{array}{l}325^{\circ} \\
300 \mathrm{~km}\end{array}$ \\
\hline 6 & $16 / 13$ & $16 / 21$ & $\begin{array}{l}235^{\circ} \\
500 \mathrm{~km}\end{array}$ & $\begin{array}{l}240^{\circ} \\
510 \mathrm{~km}\end{array}$ & $\begin{array}{l}243^{\circ} \mathrm{F} \\
520 \mathrm{~km}\end{array}$ & $\begin{array}{l}300^{\circ} \mathrm{F} \\
130 \mathrm{~km}\end{array}$ & $\begin{array}{l}030^{\circ} \\
170 \mathrm{~km}\end{array}$ & $\begin{array}{l}030^{\circ} \\
370 \mathrm{~km}\end{array}$ \\
\hline 7 & $17 / 10$ & $17 / 13$ & $\begin{array}{l}035^{\circ} \\
340 \mathrm{~km}\end{array}$ & $\begin{array}{l}030^{\circ} \\
340 \mathrm{~km}\end{array}$ & $\begin{array}{l}035^{\circ} \mathrm{F} \\
290 \mathrm{~km}\end{array}$ & $\begin{array}{l}045^{\circ} \mathrm{F} \\
360 \mathrm{~km}\end{array}$ & $\begin{array}{l}065^{\circ} \\
160 \mathrm{~km}\end{array}$ & $\begin{array}{l}340^{\circ} \\
150 \mathrm{~km}\end{array}$ \\
\hline 8 & $28 / 01$ & $28 / 03$ & $\begin{array}{l}165^{\circ} \\
320 \mathrm{~km}\end{array}$ & $\begin{array}{l}160^{\circ} \\
350 \mathrm{~km}\end{array}$ & $\begin{array}{l}166^{\circ} \mathrm{F} \\
410 \mathrm{~km}\end{array}$ & $\begin{array}{l}170^{\circ} \mathrm{F} \\
440 \mathrm{~km}\end{array}$ & $\begin{array}{l}185^{\circ} \mathrm{F} \\
500 \mathrm{~km}\end{array}$ & $\begin{array}{l}185^{\circ} \\
4 \mathrm{~km} 80\end{array}$ \\
\hline 9 & $28 / 04$ & $28 / 07$ & $\begin{array}{l}160^{\circ} \\
330 \mathrm{~km}\end{array}$ & $\begin{array}{l}166^{\circ} \mathrm{F} \\
410 \mathrm{~km}\end{array}$ & $\begin{array}{l}190^{\circ} \mathrm{F} \\
500 \mathrm{~km}\end{array}$ & $\begin{array}{l}190^{\circ} \mathrm{F} \\
500 \mathrm{~km}\end{array}$ & $\begin{array}{l}185^{\circ} \\
470 \mathrm{~km}\end{array}$ & $\begin{array}{l}175^{\circ} \\
380 \mathrm{~km}\end{array}$ \\
\hline 10 & $28 / 13$ & $28 / 21$ & $\begin{array}{l}185^{\circ} \\
490 \mathrm{~km}\end{array}$ & $\begin{array}{l}180^{\circ} \\
430 \mathrm{~km}\end{array}$ & $\begin{array}{l}175^{\circ} \mathrm{F} \\
370 \mathrm{~km}\end{array}$ & $\begin{array}{l}140^{\circ} \mathrm{F} \\
290 \mathrm{~km}\end{array}$ & $\begin{array}{l}132^{\circ} \mathrm{F} \\
280 \mathrm{~km}\end{array}$ & $\begin{array}{l}110^{\circ} \mathrm{F} \\
310 \mathrm{~km}\end{array}$ \\
\hline 11 & $28 / 22$ & $30 / 06$ & $\begin{array}{l}175^{\circ} \mathrm{F} \\
300 \mathrm{~km}\end{array}$ & $\begin{array}{l}140^{\circ} \mathrm{F} \\
290 \mathrm{~km}\end{array}$ & $\begin{array}{l}138^{\circ} \mathrm{F} \\
280 \mathrm{~km}\end{array}$ & $\begin{array}{l}195^{\circ} \mathrm{F} \\
320 \mathrm{~km}\end{array}$ & $\begin{array}{l}192^{\circ} \\
350 \mathrm{~km}\end{array}$ & $\begin{array}{l}205^{\circ} \\
330 \mathrm{~km}\end{array}$ \\
\hline 12 & $30 / 09$ & $30 / 10$ & $\begin{array}{l}178^{\circ} \mathrm{F} \\
310 \mathrm{~km}\end{array}$ & $\begin{array}{l}195^{\circ} \\
330 \mathrm{~km}\end{array}$ & $\begin{array}{l}195^{\circ} \mathrm{F} \\
360 \mathrm{~km}\end{array}$ & - & $\begin{array}{l}210^{\circ} \\
320 \mathrm{~km}\end{array}$ & $\begin{array}{l}230^{\circ} * \\
270 \mathrm{~km}\end{array}$ \\
\hline
\end{tabular}

Central two columns are the start of the fog event and the start of the last hour of the Ferryland fog event. The left two columns are $6 \mathrm{~h}$ and $3 \mathrm{~h}$ before the Ferryland fog event. The right two columns are $3 \mathrm{~h}$ and $6 \mathrm{~h}$ after the start of the last fog event hour. Text in squares is the compass direction relative to north in a clockwise sense and distance in km from Judges' Hill of a 2-m air parcel starting $24 \mathrm{~h}$ earlier. An asterisk indicates a significantly curved trajectory reversing the direction toward the end of the track. A blank indicates that the fog event lasted only $1 \mathrm{~h}$. Red correspondence to warm air over colder water advection that ended with fog at Ferryland. Pink correspondence to warm air over colder water advection that ended without fog at Ferryland. Blue correspondence to cold air over warmer water advection. Yellow correspondence to neutral air advection with air temperature near water temperature

surface fog layer occurred for seven of the events, as well as capping two of the surface layers before a fog event, which suggests that this boundary layer feature played a significant role in fog dynamics at this location.

GOES East Infrared (IR) cloud images were examined for a relationship to the Ferryland fog events. In Atlantic Canada, overcast cloud areas are associated with surface lows while narrower cloud bands extending southward are over surface troughs. In an image, these are usually white masses with orange topped cells in areas of more intense convection. The outer edges may be grey, which indicates a lower stratus top, or there may be a faint dark area, which indicates the lowest infrared detectable cloud top. The satellite infrared cloud temperatures were compared to soundings and the results presented in Table 4 are the central values for a range of approximately $\pm 5^{\circ} \mathrm{C}$. Of the 12 fog events, nine had higher clouds, and three did not. 
Table 4 Characteristics of Ferryland fog events

\begin{tabular}{|c|c|c|c|c|c|c|c|c|c|c|}
\hline \multirow{2}{*}{$\begin{array}{l}\text { Ev } \\
\#\end{array}$} & \multirow{2}{*}{$\begin{array}{l}\text { Date } \\
\text { start }\end{array}$} & \multirow{2}{*}{$\begin{array}{l}\text { Date } \\
\text { end }\end{array}$} & \multirow{2}{*}{$\begin{array}{l}\text { Dur } \\
\text { (hr) }\end{array}$} & \multirow{2}{*}{$\begin{array}{l}\text { Vis } \\
\text { Stns }\end{array}$} & \multirow{2}{*}{$\begin{array}{l}\text { Downs } \\
\text { sounding }\end{array}$} & \multicolumn{3}{|c|}{ Sat IR Cloud } & \multirow[t]{2}{*}{ Syn } & \multirow{2}{*}{$\begin{array}{l}\text { Fog } \\
\text { Cause }\end{array}$} \\
\hline & & & & & & FC & $\begin{array}{l}T \\
\left({ }^{\circ} \mathrm{C}\right)\end{array}$ & CA? & & \\
\hline 1 & $08 / 08$ & $08 / 12$ & 4 & $\mathrm{~J}, \mathrm{D}$ & S, I\&D & W & -27 & Y & $\mathrm{Tr}$ & CSCL,SB \\
\hline 2 & $12 / 15$ & $12 / 20$ & 5 & $\mathrm{~J}$ & I\&D & $\mathrm{W}$ & -40 & $\mathrm{Y}$ & $\mathrm{L}$ & CSCL,SB \\
\hline 3 & $13 / 19$ & $13 / 20$ & 1 & $\mathrm{~J}$ & S, I\&D & $\mathrm{D}$ & +11 & $\mathrm{~N}$ & $\operatorname{Tr}$ & CSCL,SB \\
\hline 4 & $13 / 22$ & $14 / 05$ & 7 & $\mathrm{~J}, \mathrm{D}$ & S, I\&D & $\mathrm{D}$ & +12 & $\mathrm{~N}$ & $\operatorname{Tr}$ & SB \\
\hline 5 & $15 / 03$ & $15 / 05$ & 2 & $\mathrm{~J}$ & -- & $\mathrm{D}$ & +11 & $\mathrm{~N}$ & $\operatorname{Tr}$ & CSCL,SB \\
\hline 6 & $16 / 13$ & $16 / 21$ & 8 & $\mathrm{~J}, \mathrm{D}$ & S, I\&D & $\mathrm{W}$ & -41 & $\mathrm{Y}$ & $\mathrm{Tr}$ & CSCL,SB \\
\hline 7 & $17 / 10$ & $17 / 13$ & 3 & $\mathrm{~J}$ & S, D & W & -32 & Y & $\operatorname{Tr}$ & CSCL,SB \\
\hline 8 & $28 / 01$ & $28 / 03$ & 2 & $\mathrm{~J}$ & S, I\&D & G & -13 & Y & $\operatorname{Tr}$ & CSCL,SB \\
\hline 9 & $28 / 04$ & $28 / 07$ & 3 & $\mathrm{~J}, \mathrm{D}, \mathrm{B}$ & $I \& D$ & DG & +2 & Y & $\mathrm{Tr}$ & SB \\
\hline 10 & $28 / 13$ & $28 / 21$ & 8 & $\mathrm{~J}, \mathrm{D}, \mathrm{B}$ & S, I\&D & DG & +4 & Y & $\operatorname{Tr}$ & CSCL,SB \\
\hline 11 & $28 / 22$ & $30 / 06$ & 32 & $\mathrm{~J}, \mathrm{D}, \mathrm{B}$ & S, I\&D & G & $\begin{array}{l}-12 \\
\text { to }-5\end{array}$ & Y & $\operatorname{Tr}$ & SB \\
\hline 12 & $30 / 09$ & $30 / 10$ & 2 & $\mathrm{~J}$ & S, D & DG & -4 & $Y$ & $\operatorname{Tr}$ & SB \\
\hline
\end{tabular}

Ev: event; Dur: Duration; Vis Stns: Stations with visibility <1 km; J=Judges' Hill; D: The Downs; B: Battery. For The Downs sounding: $S=$ saturated surface layer, I\&D indicates saturated layer capped by air temperature inversion and dry layer, D indicates saturated layer capped by dry layer only, pink highlights saturated surface layer capped by an inversion and dry layer, yellow denotes saturated layer capped by dry layer only, white denotes sounding within $4 \mathrm{~h}$ of fog and dash indicates no sounding within $4 \mathrm{~h}$ of fog. Under Satellite IR Cloud: FC is false colour, $T$ is cloud top temperature, CA? is there cloud layer above ? Under FC, $\mathrm{W}$ is white, $\mathrm{G}$ is grey, D is dark, DG is dark grey. CA? i there is a cloud layer above fog: $\mathrm{Y}$ is yes (blue), $\mathrm{N}$ is no. Syn is synoptic feature based on NARR SLP: Tr is trough, $\mathrm{L}$ is low. Under Fog Cause: CSCL is cyclonic system cloud lowering and SB is stratus base broadening downward

A study was done of the September 2018 NARR SLP analyses to detect if the conditions within about $100 \mathrm{~km}$ of Ferryland were cyclonic, neutral, or anticyclonic. It was found that all fog events occurred with only cyclonic conditions and none occurred with neutral or anticyclonic conditions. All of the fog events occurred with the axis of a weak trough and GOES IR cloud band (one was a dark area) over Ferryland. For long lasting event 11, five cloud covers are given, one for each satellite image. Thus, the cause of all Ferryland significant fog events was related to the central axis of a cyclonic event passing overhead, indicated by GOES IR and NARR sea-level pressure analysis. Every instance of fog occurred with an eastward moving satellite detected infraredcloud overhead.

We now examine the conditions at the beginning of each of the 12 Ferryland fog events to delineate possible relationships. The measured variables around the starting time of each Ferryland fog event are shown in Table 5. The most sensitive is the visibility with its rapid response to boundary-layer changes. Judges' Hill visibility was usually the first station to respond, with the lowest value for the event and often changing visibility from greater than $10 \mathrm{~km}$ to less than $1 \mathrm{~km}$ within a few minutes noted with "fa" (fast in table). The other stations responded more slowly, not declining as much, and often not lowering to fog or sometimes not even mist visibilities at the start of the event. This is consistent with a cloud base lowering to Judges' Hill first and usually not continuing downward to reach the lower stations of the Downs or Battery.

Consistent with the visibility response is the ceilometer maximum backscatter base height (a cloud base) that was formed or pre-existed, then descended to $100 \mathrm{~m}$ or the surface with the initiation of each fog event. This is evidence of the direct role of the stratus lowering and broadening in formation of fog for each event. At the same time the stratus lowered, the relative humidity increased from about $88-89 \%$ to $95-97 \%$ for eight 
Table 5 Ferryland variables around onset

\begin{tabular}{|c|c|c|c|c|c|c|c|c|c|}
\hline \multirow[t]{2}{*}{ Ev \# } & \multirow[t]{2}{*}{ Vis $\mathbf{J}(\mathrm{km})$} & \multirow[t]{2}{*}{ Vis $\mathrm{D}(\mathrm{km})$} & \multirow[t]{2}{*}{ Vis B $(\mathrm{km})$} & \multicolumn{2}{|c|}{$\begin{array}{l}\text { Precipitation } \\
(\mathrm{mm})\end{array}$} & \multicolumn{2}{|c|}{$\mathrm{WD}\left({ }^{\circ}\right)$} & \multirow[t]{2}{*}{$R H(\%)$} & \multirow[t]{2}{*}{ Base $\mathrm{Ht} \mathrm{m} \times 100$} \\
\hline & & & & Pre-Ev & Ev & Onset & End & & \\
\hline 1 & $0.1 \mathrm{fa}$ & 0.3 & 0.7 & 0 & 0.06 & 240 & 170 & inc & - \\
\hline 2 & $0.2 \mathrm{fa}$ & 1.1 & 2.3 & 0.9 & 4.1 & 170 & 175 & inc & 13 to 1 \\
\hline 3 & $0.5 \mathrm{fa}$ & 13.4 & 15.0 & 0 & 0 & 20 & 20 & inc & 4 to 1 \\
\hline 4 & $0.2 \mathrm{fa}$ & 0.2 & 0.8 & 0 & 0.02 & 0 & 345 & stdy & 2 to 1 \\
\hline 5 & $0.3 \mathrm{~h}$ & 4.8 & 6.5 & 0 & 0 & 210 & 190 & inc & 3 to 1 \\
\hline 6 & 0.1 & 0.8 & 1.4 & 3.6 & 0.5 & 50 & 15 & inc & 9 to $\mathrm{sfc}$ \\
\hline 7 & $0.1 \mathrm{fa}$ & $1.9 \mathrm{fa}$ & $2.6 \mathrm{fa}$ & 0 & 0.1 & 105 & 170 & inc & 3 to $\mathrm{sfc}$ \\
\hline 8 & 0.2 & 1.8 & 1.8 & 1.0 & 0.9 & 180 & 180 & inc & 5 to 1.8 \\
\hline 9 & $0.2 \mathrm{fa}$ & 0.2 & 0.3 & 1.6 & 0.7 & 150 & 10 & stdy & 2 to $\mathrm{sfc}$ \\
\hline 10 & $0.1 \mathrm{~h}$ & 0.2 & 0.4 & 0.5 & 2.2 & 350 & 60 & inc & 3 to $\mathrm{sfc}$ \\
\hline 11 & 0.1 & 0.1 & $0.1 \mathrm{fa}$ & 0.8 & 1.6 & 40 & 175 & dec & 8.5 re 1.5 \\
\hline 12 & $0.4 \mathrm{fa}$ & 1.2 & 2.1 & 0.9 & 1.4 & 25 & 350 & dec & 10 irr to sfc \\
\hline
\end{tabular}

Vis is visibility at J (Judges' Hill), D (the Downs), and B (Battery). Transition is fa (fast), hr (over an hour). Precip Pre-ev is total precipitation $6 \mathrm{~h}$ before event, Precip Ev is total precipitation during event. $R H$ is relative humidity: inc is increase, stdy is steady, dec=decrease before event. Base Ht is base height of Ceilometer maximum backscatter, sfc is surface, re indicated that base disappears and reappears at lower level, irr indicates irregular strength

of the 12 cases and was steady for two more. The two decreasing cases followed closely a previous fog event.

Precipitation was uneven, ranging from zero to near $4 \mathrm{~mm}$ for both the pre-event and event. Precipitation can have a role in instigating fog by cloud broadening (Tardif 2017; Koračin 2017). During the fog event, the visibilities at the three stations were uncorrelated with the precipitation rate, which varied widely (not shown)—consistent with Gultepe and Milbrandt (2010).

Wind directions at the onset were northerly about $1 / 3$ of the time and about $1 / 3$ were southerly. The latter is the direction associated with warm air advection. However, the HYSPLIT model back-trajectory analysis presented earlier shows that the bulk of these during non-event periods did not result in fog while other analysis show that the timing of fog was determined by a trough or low-pressure passage.

During the events, the median wind speeds ranged from $1.1 \mathrm{~m} \mathrm{~s}^{-1}$ (weak) to $8.4 \mathrm{~m} \mathrm{~s}^{-1}$ (strong) see Table 6. The total kinetic energy, a function of the wind speed, also had a significant range. While this variable has been related to fog formation and maintenance (Kim and Yum 2017a) there was no significant change in this variable around the onset nor was there a persistent value during the events, which suggests that its variation was not a major factor to fog formation. Similarly, net longwave radiation did not change systematically with fog onset while the median values of the events were modest, between -13 to $+1 \mathrm{~W} \mathrm{~m}^{-2}$ for all but one event. Air temperature median values also had a limited range and were not usually related to the wind direction.

The variables in this section are consistent with the fog being caused by cyclonic system cloud lowering and stratus broadening. This will be explained in Sect. 4.3. 

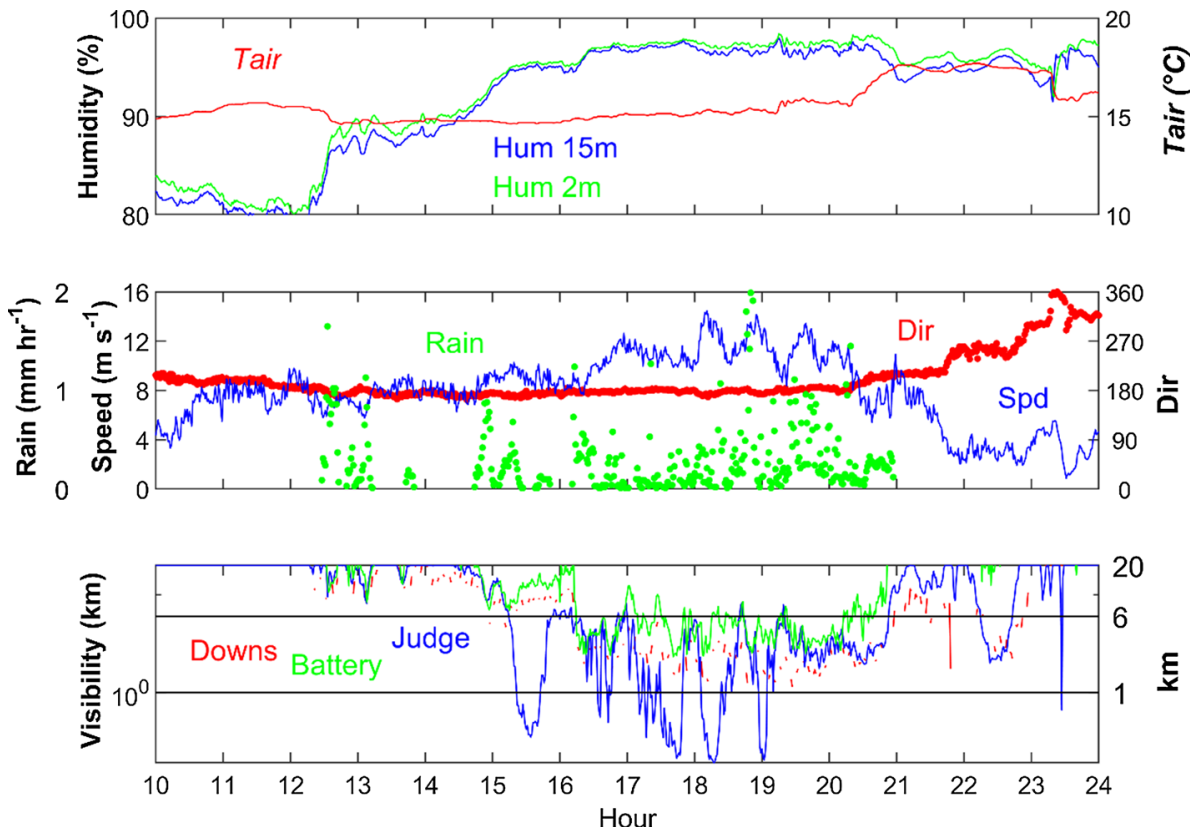

Fig. 3 Ferryland visibilities for Judges' Hill, The Downs and Battery and meteorological variables for Battery for 12 September 2018 . Horizontal lines mark the visibility thresholds for fog (visibility $<1 \mathrm{~km}$ ) and mist $(1-6 \mathrm{~km})$. The green dots with a scale in the middle frame is the rain rate in $\mathrm{mm} \mathrm{h}^{-1}$

\subsubsection{Ferryland 12 September 2018 Fog Event \# 2}

A fog event occurred in Ferryland on 1500-1900 UTC 12 September (Fig. 3). Judges' Hill was the only one of the three visibility sensors with values less than $1 \mathrm{~km}$ (Gultepe et al. 2019) and lowest values were under $100 \mathrm{~m}$. Visibility at the Downs decreased to $1-2 \mathrm{~km}$ (lower mist values). The Battery site reported visibility minima around 4-6 km (upper range in mist values). We find that $1-6 \mathrm{~km}$ visibility is a good marker of near-fog conditions due to water droplets (1 km and $6 \mathrm{~km}$ are marked on Fig. 3). This is also the range of "mist" visibility for the International Civil Aviation Organization present weather code (ICAO 2007) although the Federal Aviation Administration defines mist as having the visibility of $1.8-11.1 \mathrm{~km}$ (FAA 2017). Relative humidity increased quickly so as to exceed $93 \%$ when Judges' Hill visibility first fell below $1 \mathrm{~km}$. After an initial increase around sunrise (0904 UTC), the air temperature decreased and remained rather steady during the fog period and increased again after the fog dissipated. Intermittent rain began around 1200 UTC as the visibility started to decrease. Rain was fairly continuous but irregular in rate from about 1500 UTC to 2100 UTC. The onset of precipitation coincided with an increase in relative humidity.

The time-height cross-section of the ceilometer backscatter coefficient $(\beta)$ at the Downs site is shown to give an impression about the boundary-layer structure and variability (Fig. 4). Before 1200 UTC, there was only a weak backscatter from within a 300-400 m deep surface layer. Shortly after 1200 UTC, precipitation results in higher backscatter extending to heights well above the $1500 \mathrm{~m}$ image limit. This precipitation may be related to stratus broadening. Around 1400 UTC a stratus cloud base layer formed at $600 \mathrm{~m}$. With the second onset of precipitation around 1500 UTC, the stratus quickly lowered to form 


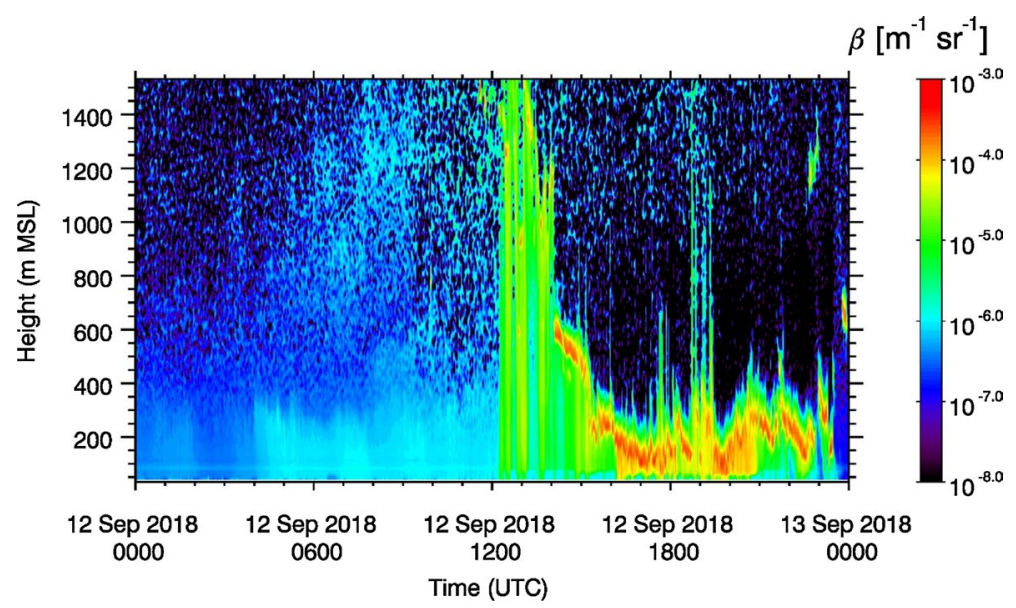

Fig. 4 Time-height cross-section of the ceilometer backscatter coefficient $(\beta)$ at the Downs site for 12 September 2018. Red colours show highest backscatter, indicating a cloud base. Note that the elevation of Judges' Hill site is $95 \mathrm{~m}$ above mean sea level (MSL)

fog at Judges' Hill, lifted to $200 \mathrm{~m}$, and then dropped again quickly to the surface after 1600 UTC. After this, the cloud base was near or at the surface as $\beta$ and base height varies with Judges' Hill visibility. Just before 2100 UTC, with the cessation of precipitation, the cloud base promptly lifted up to $300 \mathrm{~m}$. After this there are three oscillations of the cloudbase height followed by its disappearance. The ceilometer data collected at the Downs visualizes the formation of the stratus cloud base and its descent to the surface and thus indicates that stratus-cloud lowering and broadening caused the fog.

Soundings at the Downs bracketing the 12 September Ferryland fog event are shown in Fig. 5. Before the event, the surface layer was deep, well mixed but not very moist with a $14 \mathrm{~m} \mathrm{~s}^{-1}$ wind jet from the $200 \mathrm{deg}$ direction. This was capped by a very dry layer with a weak temperature inversion based at $1.5 \mathrm{~km}$. After the event, the surface layer thinned to $0.6 \mathrm{~km}$ while the upper half remained saturated. The maximum wind speed decreased to $9 \mathrm{~m} \mathrm{~s}^{-1}$ but was distributed over $0.2 \mathrm{~km}$ to $0.8 \mathrm{~km}$, and the wind direction shifted to the north. The surface layer had near neutral stability while the base of the inversion was stable for both soundings. This is consistent with a trough passing overhead between the soundings.

The GOES IR images are useful for tracking the movement of cyclonic systems across Atlantic Canada. A number of cyclonic systems form in the north-east U.S., then move eastward. At 1200 UTC 12 September 2018, an eastward moving cloud mass covered Newfoundland, while the Gulf of St. Lawrence was clear of clouds (Fig. 6a). The Ferryland fog event was initiated under this cloud band $3 \mathrm{~h}$ later. The fog dissipated when the cloud band shifted east so that Newfoundland and surrounding waters were clear of clouds by 0000 UTC 13 September (Fig. 6b).

The cyclonic system associated with this fog occurrence had its greatest amplitude at sea level as a closed low pressure system moving eastward. At 1800 UTC 12 September, the low was centred over the southern coastline of Newfoundland, producing stronger winds from the south at Ferryland, which is coincident with the densest fog at Judges' Hill (Fig. 6c). By 0000 UTC 13 September, the low centre had moved to the eastern side of the Avalon Peninsula (not shown) and caused dryer surface air from the north-north-west to flow across Newfoundland, clearing the sky and dissipating the Ferryland fog. 


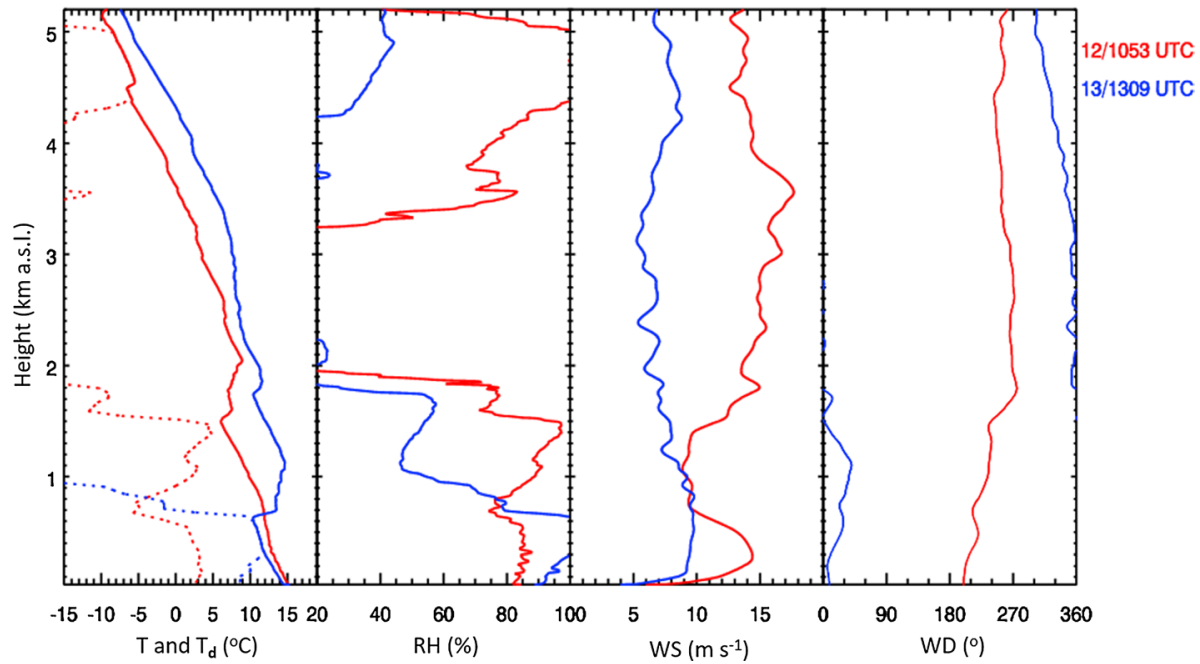

Fig. 5 The Downs soundings at 1053 UTC 12 September 2018 (red) and 1309 UTC 13 September 2018 (blue) taken before and after event \# 2 fog occurred between 1500 and 2000 UCT on 12 September

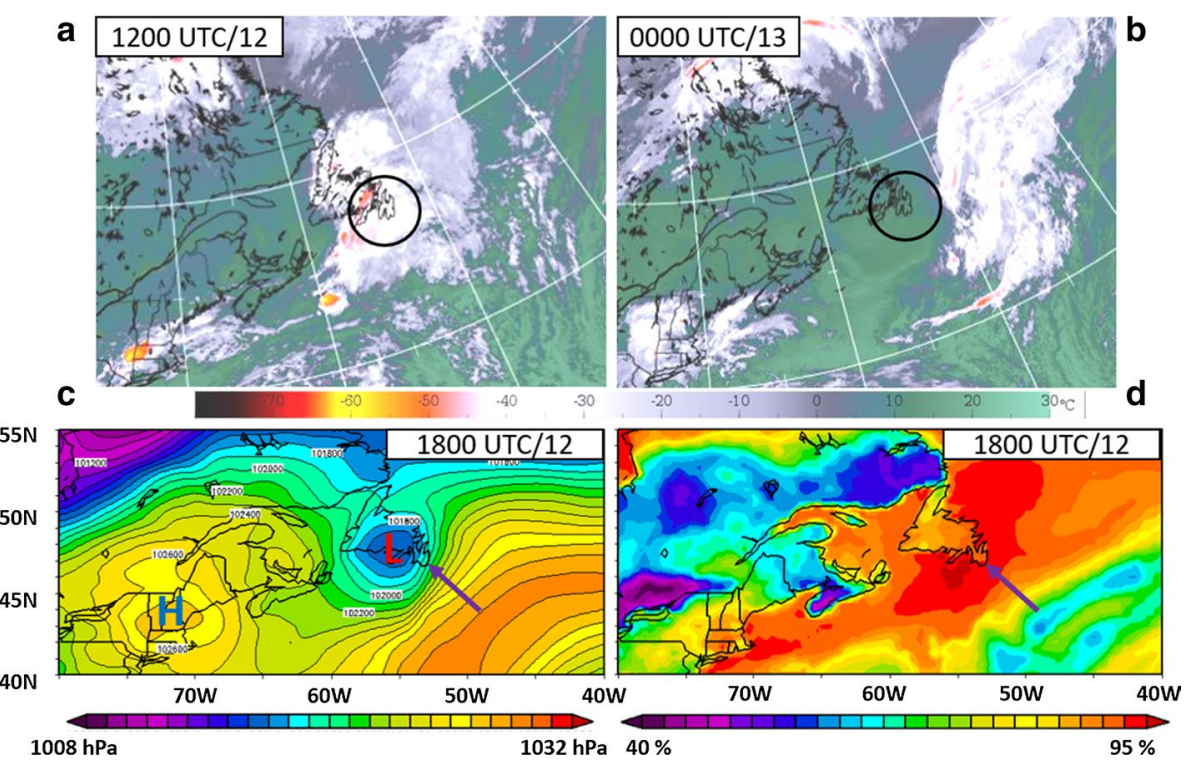

Fig. 6 Analyses for the 12 September fog event. GOES East IR images for 1200 UTC 12 September (a) and 0000 UTC 13 September (b). At 1800 UTC 12 September is the NARR sea-level pressure (c) and 2-m $R H$ (d). NARR Reanalysis provided by the NOAA/OAR/ESRL PSD, Boulder, Colorado, USA, at https://www. esrl.noaa.gov/psd/. Satellite images from Environment Canada at https://weather.gc.ca/satellite/index_e. html

Before the fog event, NARR analysis showed that an area with 2-m humidity greater than $95 \%$ moved eastward along the coast between New York and Newfoundland. At 1800 

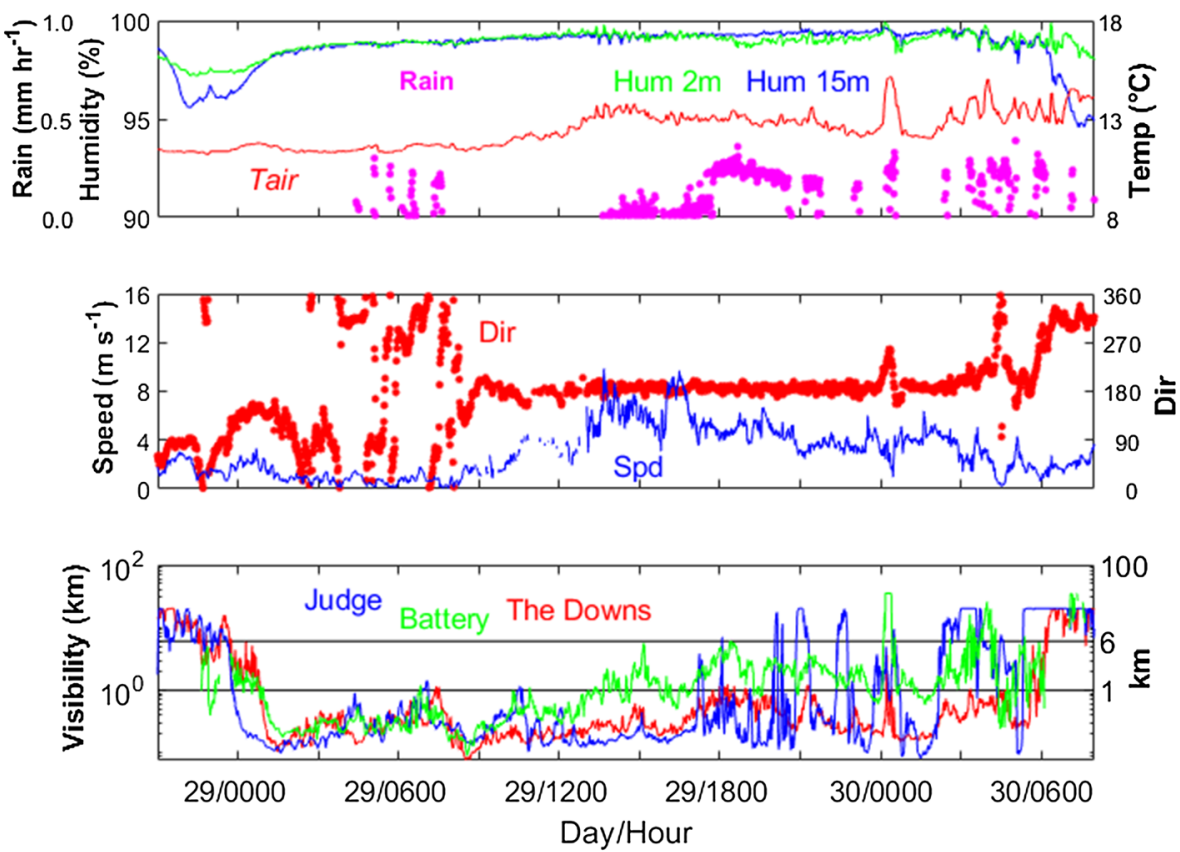

Fig. 7 Ferryland visibilities for Judges' Hill, the Downs, and Battery sites and meteorological variables for Battery for 28-30 September 2018. Horizontal lines in the lowest frame mark the visibility thresholds for fog (vis $<1 \mathrm{~km})$ and mist $(1-6 \mathrm{~km})$. The purple dots in the upper frame are the rain rate and the scale in $\mathrm{mm}$ $\mathrm{hr}^{-1}$ is the vertical line with tic marks in the central portion of the frame

UTC and the time of the fog, the 2-m humidity above $95 \%$ was concentrated around Ferryland and all of Newfoundland except the western coast (Fig. 6d).

In summary, this case study showed that a cyclonic system formed and lowered stratus over an area around Ferryland (Fig. 6a, c). Stratus broadening with cloud-top radiation, precipitation (Fig. 3), and warm-air advection (HYSPLIT back trajectory Table 3) contributed to increasing the surface temperature (Table 6) and the surface relative humidity around the low pressure (Fig. 6d, Table 5), resulting in broadening the cloud base downward to the surface (soundings, Fig. 5, ceilometer image Fig. 4), and forming the fog (Fig. 3). When the cyclonic system moved on to the east (Fig. 6b) the fog dissipated.

\subsubsection{Ferryland 28-30 September 2018 Extended Fog Event \# 11}

The longest fog event occurred from 2200 UTC 28 September to 0600 UTC 30 September 2018 (Fig. 7). The unusual length was on account of two large synoptic scale features: a deep polar low to the north and a tropical cyclone to the south. Visibility at all three Ferryland stations decreased after 2200 UTC 28 September and remained below $1 \mathrm{~km}$ until about 1400 UTC 29 September. Thereafter visibility at Battery varied between $<1 \mathrm{~km}$ and $3 \mathrm{~km}$ while the other two remained mostly below $1 \mathrm{~km}$. Around 0600 UTC 30 September all visibility measurements increased to greater than $10 \mathrm{~km}$. The winds were light and the direction switched from northerly to easterly. After 0900 UTC 29 September the wind direction changed to south and remained so for the rest of 


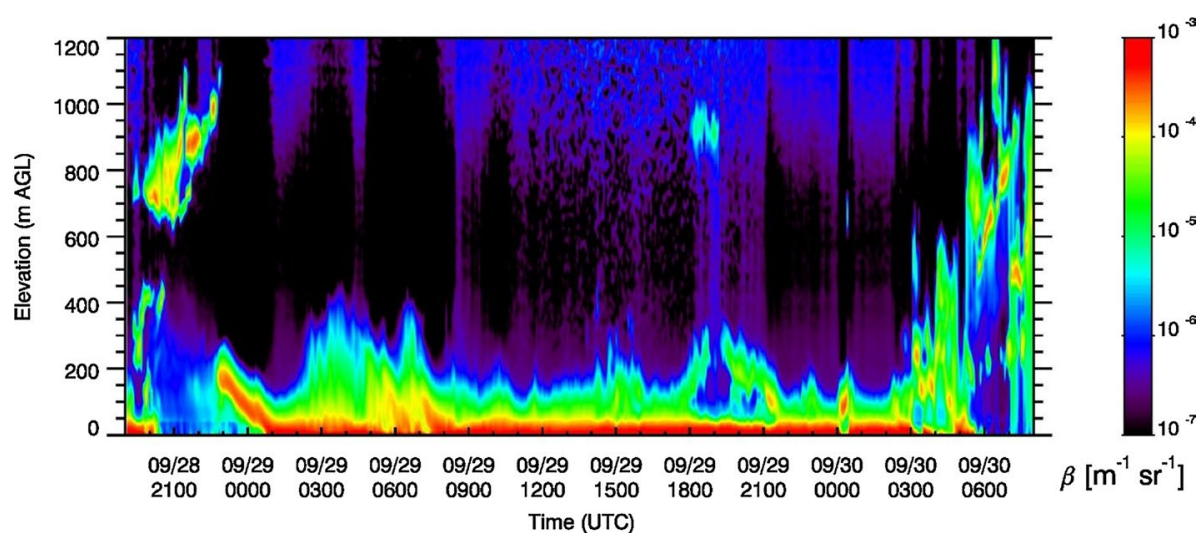

Fig. 8 Time-height cross-section of aerosol backscatter coefficient at the Downs, Ferryland, 2000 UTC 28 September 2018 to 0800 UTC 30 September 2018. Red colours indicate the strong backscatter in the stratus cloud/fog layer

the event. The end of the event occurred when the wind direction switched to northwest. However, rain was sporadic. There were periods of fog visibilities without rain from the beginning of the event until after 0400 UTC 29 September and from 0800 UTC 29 September until after 1400 UTC 29 September. From 2100 UTC to after 0000 UTC 30 September, there was continuous visibility less than $1 \mathrm{~km}$ but intermittent periods of precipitation. Fog occurred continuously but rain was intermittent, and rate varied considerably_visibility and precipitation were not well related in this event.

The changes in the boundary layer for this event that extended from 1900 UTC 28 September to 0800 UTC 30 September are revealed in the Downs ceilometer image (Fig. 8). Around 2100 UTC 28 September the boundary layer was clear from the surface to $700 \mathrm{~m}$. At 2200 UTC, a cloud base formed at $200 \mathrm{~m}$ and descended to the surface after 0000 UTC 29 September. The base remained at the surface with a few short breaks, until around 0600 UTC 30 September when it disappeared. After this, it was clear at the surface with irregular backscatter returns at 500-900 m. The initial layer formation and its descent is consistent with stratus broadening.

The Downs soundings before and during Ferryland fog event \# 11 reveal the structure of the lower atmosphere and boundary layer during fog (Fig. 9). The commonalities in the 8 soundings during the event highlight the fog boundary layer conditions. For 7 of the 8 soundings during the event, this included a surface-based inversion, a saturated (or nearly saturated) layer extending from surface to above $0.6 \mathrm{~km}$, and a capping dry layer of various strength and depth. Wind speeds increased from the surface to a weak maximum around $0.5 \mathrm{~km}$. Wind directions ranged from north-east, south, to north-west at the surface and converged to west-south-west above $1.5 \mathrm{~km}$.

The 2123 UTC 28 September sounding (dotted line in Fig. 9) was before the event when visibilities were greater than $6 \mathrm{~km}$ and the ceilometer backscatter was low (Fig. 8). This pre-event sounding differed from the event soundings with a shallow well-mixed surface layer capped around $0.2 \mathrm{~km}$ by a subsidence inversion base and dry layer. Also, a surface jet was centred at $0.2 \mathrm{~km}$, and surface winds were from the east.

The NARR SLP analysis for 0000 UTC 29 September shows a deep low to the northwest of Ferryland along $70^{\circ} \mathrm{W}$, a moderate low over central Nova Scotia that extended over Newfoundland, and tropical cyclone Leslie to the south-east $\left(35.9^{\circ} \mathrm{N} 48.9^{\circ} \mathrm{W}\right)$ (Fig. 10a). 


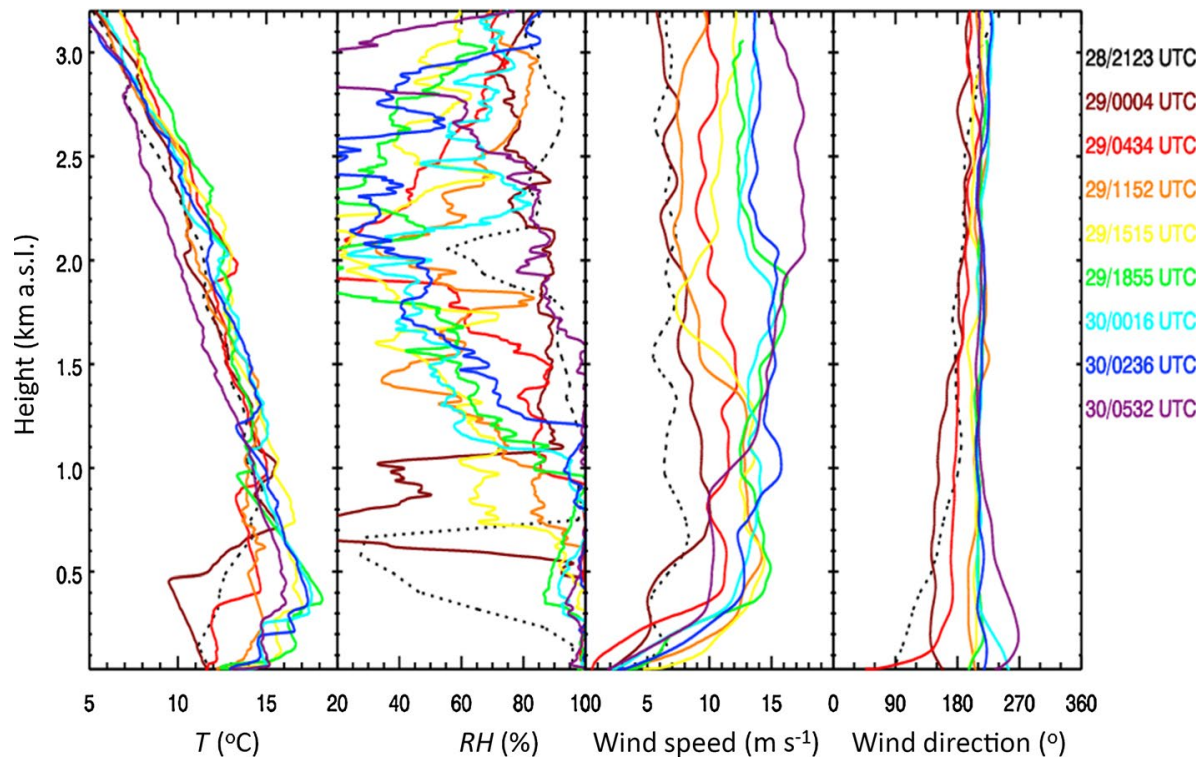

Fig. 9 The Downs radiosondes for event \# 11 on 28-30 September 2018. Soundings for 0004 UTC 29 September through 0532 UTC 30 September were in fog. The black dotted line is the sounding just before the fog event at 2123 UTC 28 September

By 1200 UTC 29 September, the northern low moved eastward to $65^{\circ} \mathrm{W}$ and Leslie had moved west $\left(34.7^{\circ} \mathrm{N} 50.6^{\circ}\right)$ to form a trough that extended over western Newfoundland (Fig. 10b). This trough remained over Newfoundland on 0000 UTC 30 September, forming a col to the south with Leslie (Fig. 10c). By 0600 UTC 30 September the northern low was along $50^{\circ} \mathrm{W}$ and Leslie had shifted eastward so that a trough axis was just off the east coast of the Avalon Peninsula and the col centred to the south (Fig. 10d). The overhead trough axis maintains low-level convergence, surface parcel lifting, condensation, and fog. The action of the two large-scale cyclones was to slow the eastward trough axis movement across Newfoundland to maintain fog at Ferryland for $32 \mathrm{~h}$.

The GOES East IR cloud retrievals followed the surface cyclonic system as it moved eastward. Near the beginning of the event, 0000 UTC 29 September (Fig. 11a), there were two large cloud masses. The first was over northern Quebec with a cloud band extending to the south and west over the USA. The second was over eastern Quebec and Newfoundland with a cloud line extending to the south-west over Newfoundland and Nova Scotia and the surface low there. On 1200 UTC 29 September, the centre of the northern low had shifted to the east so that half of the northern low centre was over the Labrador Sea (Fig. 11b). By 0000 UTC 30 September the cloud-band centre shifted east and narrowed but it still extended across the Avalon Peninsula (Fig. 11c). Finally, at 0600 UTC 30 September, the northern cloud mass covered the Labrador Sea, Greenland, and extended into the north Atlantic (Fig. 11d). The southern cloud-band extension had narrowed, and its main axis was just east of the Avalon Peninsula, which coincided with the end of the Ferryland fog event.

In summary, this case study confirms the role of a cyclonic system for causing fog. An eastward-moving trough (Fig. 10) lowered clouds in a preceding fog event which included precipitation and high relative humidity (Table 5, event \#10). Then there was a brief 


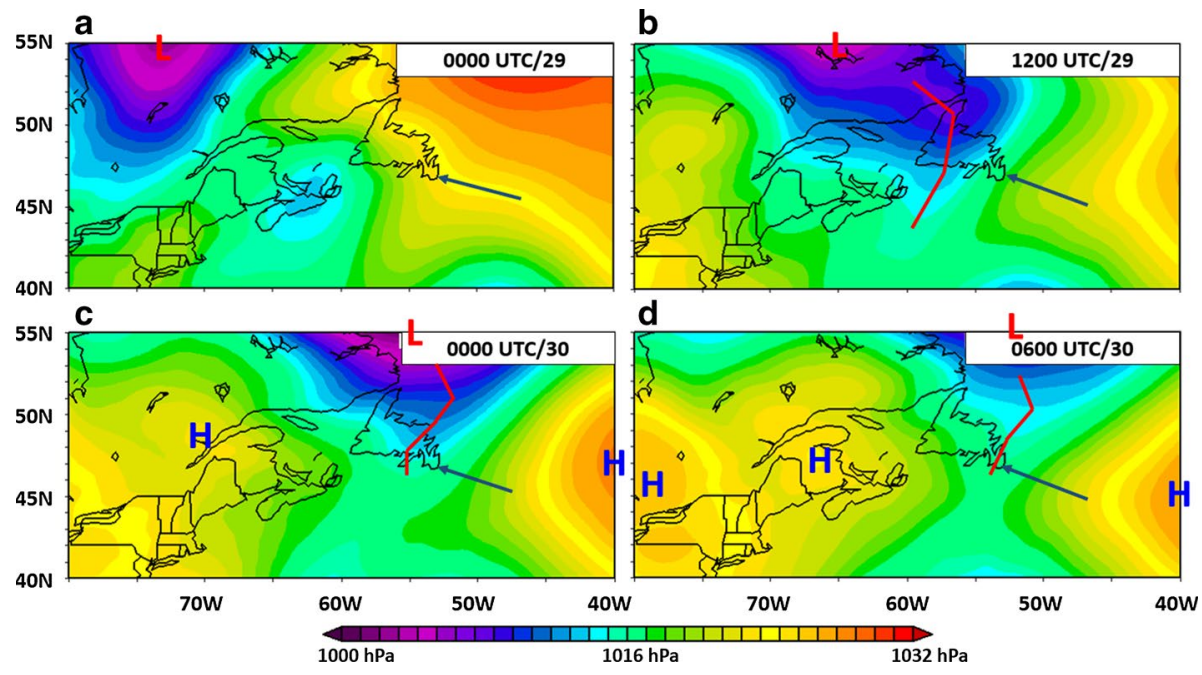

Fig. 10 NARR SLP analyses for 0000 UTC 29 September-0600 UTC 30 September. A trough axis is marked by red line. The southern low just off the southern edge of the analysis is Tropical Storm Leslie. Blue arrows point to Ferryland. NARR Reanalysis provided by the NOAA/OAR/ESRL PSD, Boulder, Colorado, USA, at https://www.esrl.noaa.gov/psd/
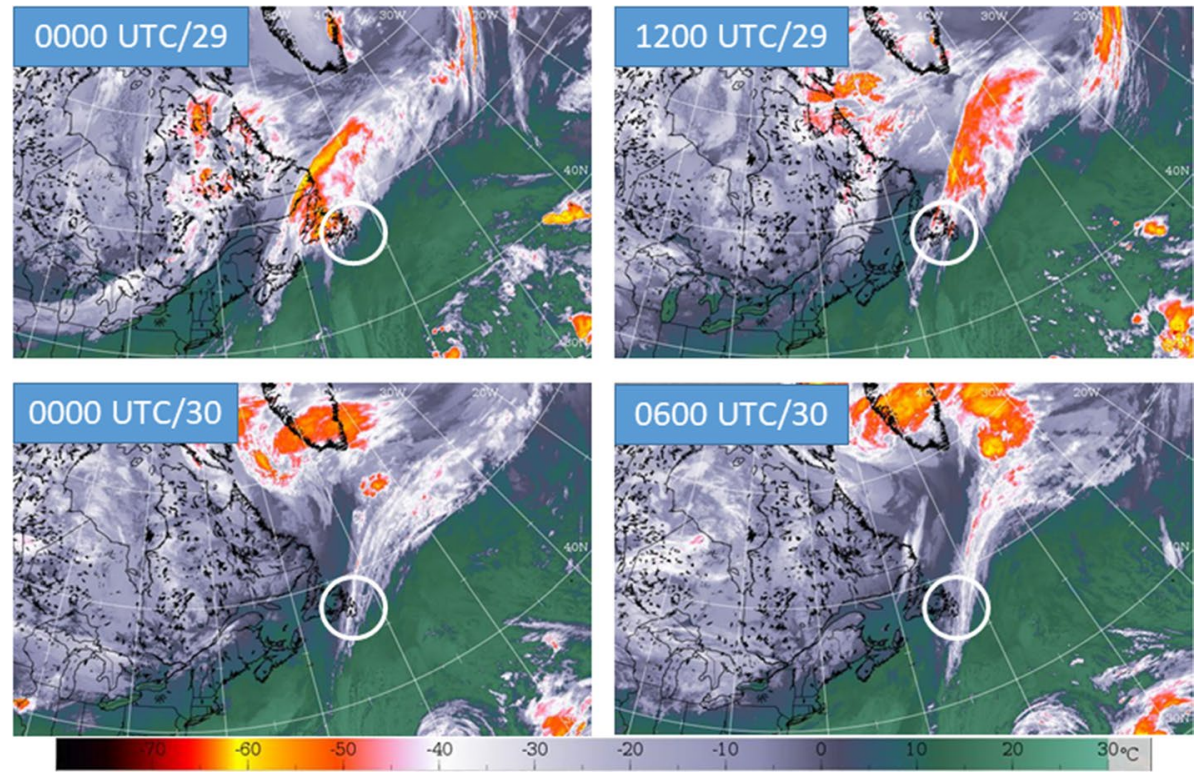

Fig. 11 GOES East IR images for 0000 UTC 29 September to 0000 UTC 30 September. Clouds in the images' SE corner are with Tropical Storm Leslie. White circles are centred on Ferryland. Satellite images from Environment Canada at https://weather.gc.ca/satellite/index_e.html

visibility increase and partial lifting of the cloud base. This was followed by stratus-cloud broadening and descent to the cloud base to the surface for Event \# 11 that was captured in the visibility (Fig. 7) and the ceilometer image (Fig. 8). The broadening was due to 


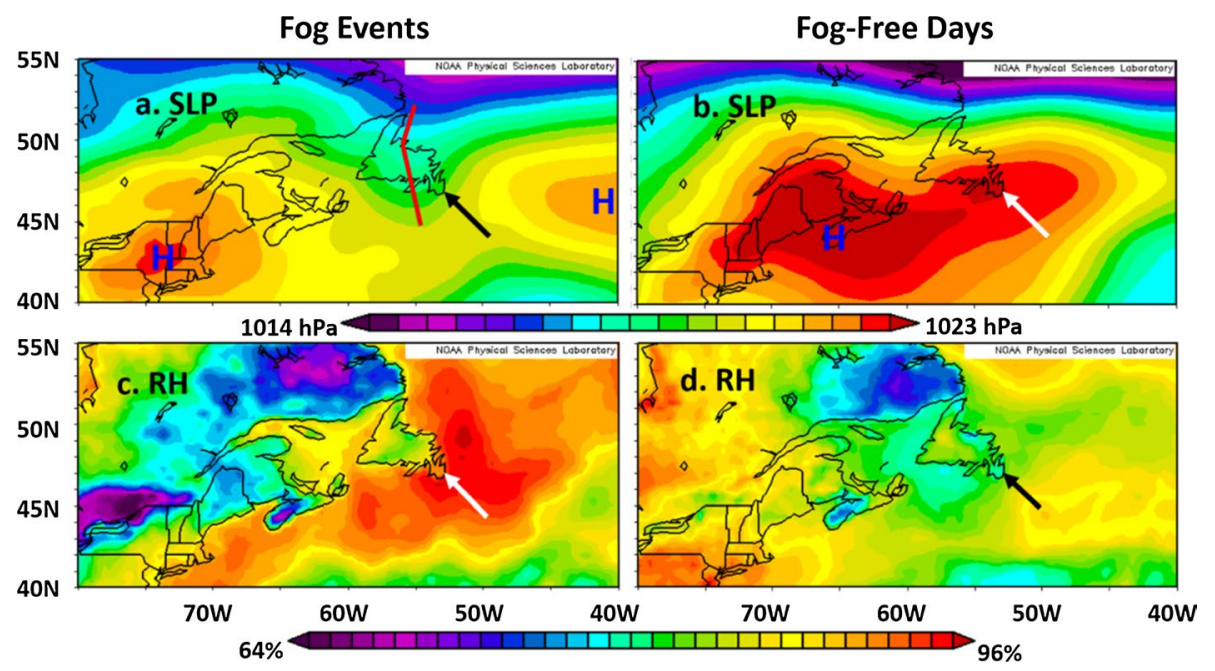

Fig. 12 NARR composites of fog events (a, c) and fog-free days (b, d). Upper panels are sea-level pressure and lower panels are 2-m relative humidity. Red line in Fig. 12a shows the trough axis position over Newfoundland. Arrows point to the Ferryland site. NARR Reanalysis provided by the NOAA/OAR/ESRL PSD, Boulder, Colorado, USA, at https://www.esrl.noaa.gov/psd/

increased low-level convergence, surface parcel lifting to condensation, assisted by warmair advection (Table 3) as well as stratus-top radiation into the clear sky (Fig. 11) encouraged by a capping inversion and dry layer (Table 4, Fig. 9). These conditions continued, maintaining the fog. The trough itself was slowed in its eastward movement by the interaction of a low to the north and Tropical Storm Leslie to the south (Fig. 10). When the trough moved on to the east (Figs. 10 and 11, 0006 UTC 30 September) the fog dissipated.

\subsubsection{Sea Level Pressure and 2-m Relative Humidity Composites of Fog Events and Fog-Free Days}

NARR SLP composites were created to compare the differences between fog events and no-fog events (Fig. 12). For each fog event in Table 2, the 3-hourly time closest to the centre of the event was selected. For the 19 fog-free days during September 2018, the 1200 UTC analysis was used. The resulting SLP composite of fog events (Fig. 12a) has a lowpressure trough over mid-Newfoundland whereas this is replaced with a high on fog-free days (Fig. 12b). For the 2-m relative humidity, the fog events composite (Fig. 12c) had a humidity maximum greater than $90 \%$ on the eastern Newfoundland coast whereas this was replaced with a relative humidity minimum of less than $80 \%$ on no-fog days (Fig. 12d). In summary, Ferryland fog days are distinctively different from fog-free days in terms of NARR SLP and 2-m humidity.

\subsubsection{Northern Avalon Peninsula Fog}

Fog events recorded at northern Avalon Peninsula stations are presented for a comparison with Ferryland (Table 1, Fig. 1). St. Johns' Airport had 55 fog hours in 10 events, the most of the three northern AP stations for September 2018 (Table 7). The C-FOG station at Blackhead had 22 fog-hours in five events while the Flatrock C-FOG station had 11 
fog-hours in six events. Blackhead and Flatrock had the least fog-hours compared to all other AP stations. The fog occurrences at northern AP stations were not especially related to the diurnal cycle nor to fog at Ferryland (Table 2).

The lack of a relationship between fog occurrence at Ferryland and the northern AP stations separated by less than $78 \mathrm{~km}$ was unexpected as they are close enough to be under the same synoptic weather conditions. This suggests that local topography, which affects the mesoscale, was a controlling factor on the processes that determine fog.

\subsection{Sable Island Fog}

\subsubsection{Sable Island Overview}

Sable Island is Atlantic Canada's south-eastern most station that is on the outer edge of the continental shelf and has the least land influence. Sable Island fog events are listed in hourly blocks (Table 8) as was done for Ferryland (Table 2). In September 2018, there were 22 fog-hours in six events. The longest event lasted $12 \mathrm{~h}$ on September 29th, which is coincident with the longest fog event at Ferryland and SLP interaction between a deep low to the north and a tropical cyclone to the south.

To test the possible role of advection in generating the Sable Island fog events, back trajectories were generated with HYSPLIT (Table 9) as was done for Ferryland and was explained in Sect. 3.2.1. The central column is the back trajectory at the start hour of the fog event and at the start of the last hour of the event. The last hour was left blank if the event only occurred during one hour. To further examine possible near-event shifts, back trajectories are given $6 \mathrm{~h}$ before the fog event and $6 \mathrm{~h}$ after the last hour of the fog event.

The advection type was determined using an SST field for the September long-term mean constructed from the NOAA OI SST V2 High Resolution data provided by the NOAA/OAR/ESRL PSL, Boulder, Colorado, USA, at https://psl.noaa.gov/ (Reynolds et al. 2002). The SST isotherms were oriented along $250^{\circ}-085^{\circ}$ in the vicinity of Sable Island. Neutral surface advection was oriented within $\pm 20^{\circ}$ of this direction. Warm-air advection was from $105-175-230^{\circ}$

For the start hour of the six fog events, back-trajectory warm air over cold-water advection occurred with fog three times, cold air over warm water occurred two times and neutral air advection once. It is also of note that in the six hours before and six hours after the fog events, there were five cases of warm air over cold water back-trajectory (pink colour) that did not result in fog. There were more of the latter cases occurring during the remainder of the September hours, not shown here. The conclusion is that advection is not a controlling factor for fog at Sable Island. It will be shown that a cyclonic feature crossing or an anticyclonic centre overhead, are the factors that control fog formation here.

Four of the six Sable Island September fog events occurred when the axis of a weak trough passed overhead (Table 10). These coincided with GOES IR and visual cloud bands. The satellite IR cloud temperatures were compared to soundings and the results presented in Table 10 are the central values for a range of approximately $\pm 5{ }^{\circ} \mathrm{C}$. Of the six events, two of the cloud tops in the satellite IR images were higher clouds and four were the fog-layer top itself. Events 1 and 4-6 followed the same sequence, starting with the formation of a low cloud base. The base gradually lowered while surface visibility remained high until the cloud dropped below $300 \mathrm{~m}$ elevation. After this, further cloud base lowering occurred with a decline in visibility and until fog formed under the trough 

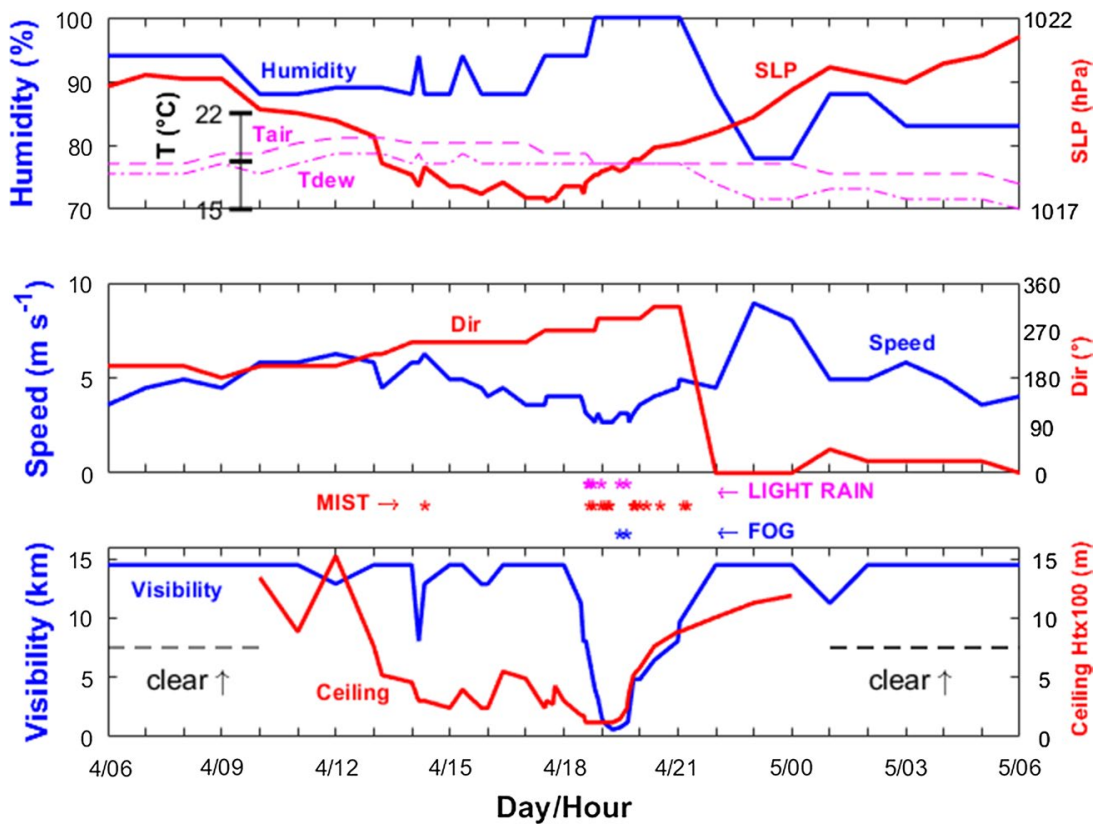

Fig. 13 Sable Island surface meteorological variables for 0600 UTC 4 September 2018-0600 UTC 5 September 2018. $R H$, sea level pressure, air temperature, and dew point are plotted in the upper frame, wind speed and direction are in the middle frame. Visibility and ceiling height are in the lower frame. Clear designates when there are no clouds. Observations with fog, mist, and light rain are designated with an asterisk below the middle panel

axis. This was followed by the lifting of the cloud base and increase in visibility. All of the fog events occurring during a sounding had an air temperature inversion (three cases) while the others (three cases) had an air temperature inversion in the sounding before or after, which suggests that this a significant aspect for fog formation as it did for Ferryland. Light rain occurred intermittently during the long event (\# 5), continuously for events \# 1 , 4, and 6, and also before for all 4 cyclonic events. Event 3 began as an ephemeral, weak surface trough with a moist surface layer under a low inversion and clear sky. Low-level convergence generated low stratus that cleared briefly, and fog formed at 0200 LST by surface radiation without precipitation and under a clear sky. Event \# 2 was a surface radiation event caused by fog occurring around sunrise under clear sky and a high centre.

\subsubsection{Sable Island 4 September 2018 Cyclonic Fog Event \#1}

A case study is shown for a Sable Island cyclonic fog event. The fog event on this day was instigated by a trough axis passage at 2200 UTC 4 September (Table 11, Fig. 13). Before the trough passed, the sky was clear of clouds and winds were from the south. A cloud base formed by 1300 UTC, then multiple cloud layers developed as the lowest cloud base descended to $244 \mathrm{~m}$, wind direction shifted westward, and pressure decreased to a minimum of $1017.3 \mathrm{hPa}$ at $2030 \mathrm{UTC}$. The visibility remained mostly unchanged at $14 \mathrm{~km}$ until the cloud base lowered to $244 \mathrm{~m}$, after which both decreased until the cloud base reached $122 \mathrm{~m}$ and precipitation reached the ground. After this, the cloud base 

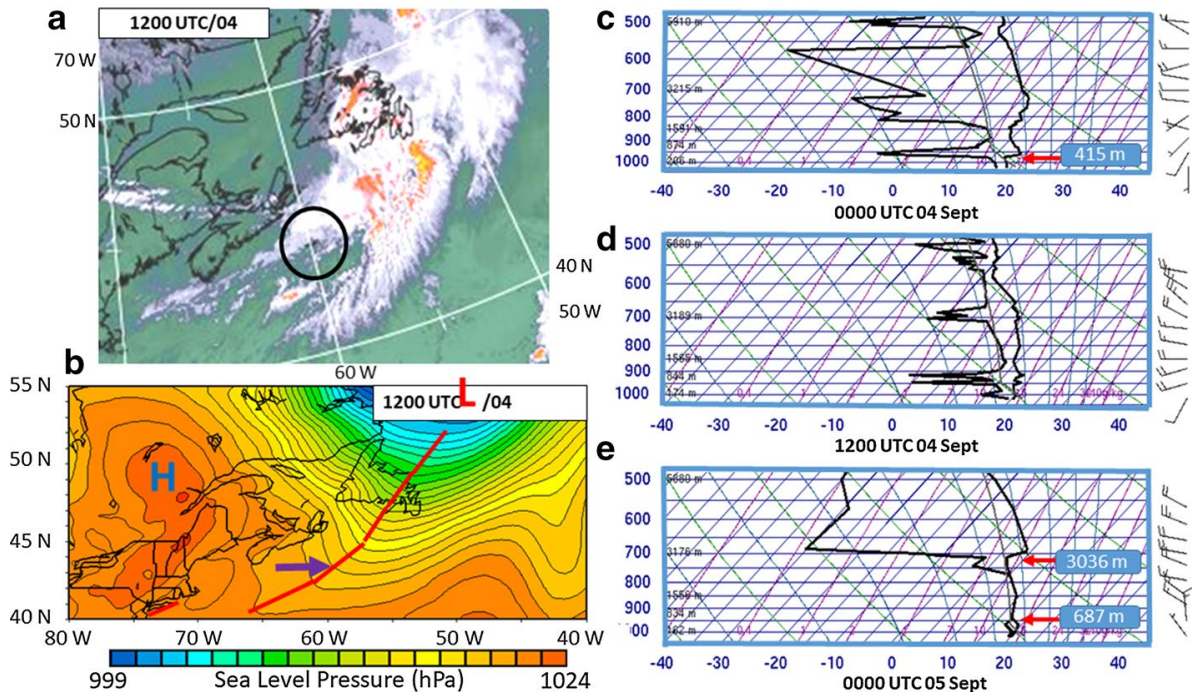

Fig. 14 Analyses for Sable Island 4-5 September fog event GOES East IR is for 1200 UTC 04 September (a). NARR sea level pressure is for 1200 UTC 04 September (b). Red line indicates the trough axis. Sable Island RAOB soundings for 0000 UTC 04 September before clouds at Sable Island (c), 1200 UTC 04 September at edge of approaching cloud band and before fog (d), and 0000 UTC 05 September after fog and as clouds were starting to clear e). Number in the blue box is the height of the air temperature inversion base. Circle surrounds and purple arrow point to Sable Island. Satellite image from Environment Canada at https://weather.gc.ca/satellite/index_e.html.Soundings are from the University of Wyoming at http://weath er.uwyo.edu/upperair/

remained nearly constant as the visibility declined to $0.61 \mathrm{~km}$. At this point, there was fog, light rain, and the ceiling obscured (VV). These conditions lasted only 23 min, after which visibility and cloud base height increased until clear sky and high visibility at 0400 UTC 5 September. Over this event, the wind direction shifted from south to west to north to north-east. The sea level pressure started high, decreased to a minimum at 2030 UTC then increased. The air temperature and dew point both decreased after 1200 UTC, with the air temperature equal to the dew point for $2149-2323$ UTC.

The GOES IR image at 1200 UTC (Fig. 14a) shows a cloud mass with cells (areas with lower cloud-top temperatures) extending from the Labrador Sea, over Newfoundland, and extending a narrow arm over Sable Island. The 1200 UTC NARR sea level pressure (Fig. 14b) shows that the clouds are related to a deep low over the Labrador Sea, and a trough passing over Newfoundland, eastern Nova Scotia and still west of Sable Island which it will pass over in $8.5 \mathrm{~h}$. The Sable Island sounding at 0000 UTC 04 September (Fig. 14c) shows a shallow moist marine layer capped by an air temperature inversion layer with dry air. Twelve hours later, as the first clouds were about to appear, the sounding indicated a moist layer up to $5 \mathrm{~km}$ elevation capped with an inversion (Fig. 14d). At 0000 UTC 5 September, after the fog and near the end of the clouds, the sounding had a shallow surface layer capped at $687 \mathrm{~m}$ by a saturated layer (Fig. 14e). Above this was an inversion base at $3036 \mathrm{~m}$ with a dry layer.

In summary, the Sable Island fog event \# 1 was brief (Table 10). An eastward moving trough (Fig. 14b) caused convergence, cloud formation and lowering (Fig. 14a, Table 11, Fig. 13). Stratus-cloud broadening was caused by low-level convergence with surface air 
lifting to condensation. The RAOB sounding about $1 \mathrm{~h}$ after the fog ending had an air temperature inversion and very dry layer capping a deep saturated layer (Fig. 14e), which likely existed during the fog and supported cloud top radiation and buoyancy mixing. Light rain before and during the fog would have contributed to stratus broadening (Table 11). However, the HYSPLIT back trajectory indicated neutral advection with no significant support for condensation (Table 9). The short fog event lasting only $27 \mathrm{~min}$ was caused by the trough axis passing over quickly followed by decreasing convergence and a wind shift that resulted in cloud base lifting and fog dissipation.

\subsubsection{Sable Island 15 September Anticyclonic Fog Event \#2}

An anticyclonic fog is presented for Sable Island as an example of radiation-caused fog in contrast to the cyclonic fog cases. At night on 15 September, the sky was clear and visibility was good up until 0600 UTC (Table 12, winds and pressure data were missing). By 0616 UTC, mist had formed and visibility decreased. The humidity was $100 \%$ for 0702-1127 UTC. Fog was observed and visibility was $0.4 \mathrm{~km}$ or less under clear skies during 0800-1053 UTC (sunrise was at 0939 UTC). At 1053 UTC the fog ended and visibility increased steadily above $1 \mathrm{~km}$. At 1127 UTC a low ceiling formed and then lifted so that there was clear skies at 1500 UTC. However, the low cloud was well after the fog clearing and not directly related to it. No precipitation was recorded with this event.

The satellite visual image about an hour after the fog ended at 1200 UTC (Fig. 15a) had a few scattered clouds around Sable Island. The 0900 UTC NARR SLP (Fig. 15b) indicated that Sable Island was under a ridge axis during the fog (blue line in Fig. 15b).

The 0000 UTC 15 September Sable Island sounding before the fog had a low moist marine layer capped at $223 \mathrm{~m}$ by a subsidence inversion and dry layer (Fig. 15c). The 1200 UTC sounding, only $33 \mathrm{~min}$ after the fog ended (Fig. 15d) showed a marine layer capped by a saturated cloud layer from 199 to $449 \mathrm{~m}$. That layer was topped by a subsidence inversion/dry layer.

In summary, this Sable Island fog event was formed by night radiation around sunrise under clear sky coincident with an anticyclone ridge overhead. This was accompanied with a low temperature inversion and cold-air advection from the north-east (Table 8).

\section{Discussion}

\subsection{Advection and Fog Occurrence}

It is a common practice to assume that fog along Atlantic Canada is caused by advection (Li et al. 2016; Dorman et al. 2017), that is by warmer air moving a long distance over colder water, one of the fog formation mechanisms cited in the introduction. It is assumed, with the temperature inversion capping the surface layer for part of the trajectory, this would increase the moisture in the layer to the point that fog would form before arriving at any measurement location. However, this is contrary to the Atlantic Canada observations. The bulk of the air trajectories at all the stations (Fig. 2) for September 2018 were from an arc of south-west to south to south-east, which is a path of warmer air traveling over increasingly colder water. Therefore, the bulk of the observations should include fog. Instead, fog-hours were only 1 to $10 \%$ of the observations. These low fog occurrences are consistent with ship-based climatology (Dorman et al. 

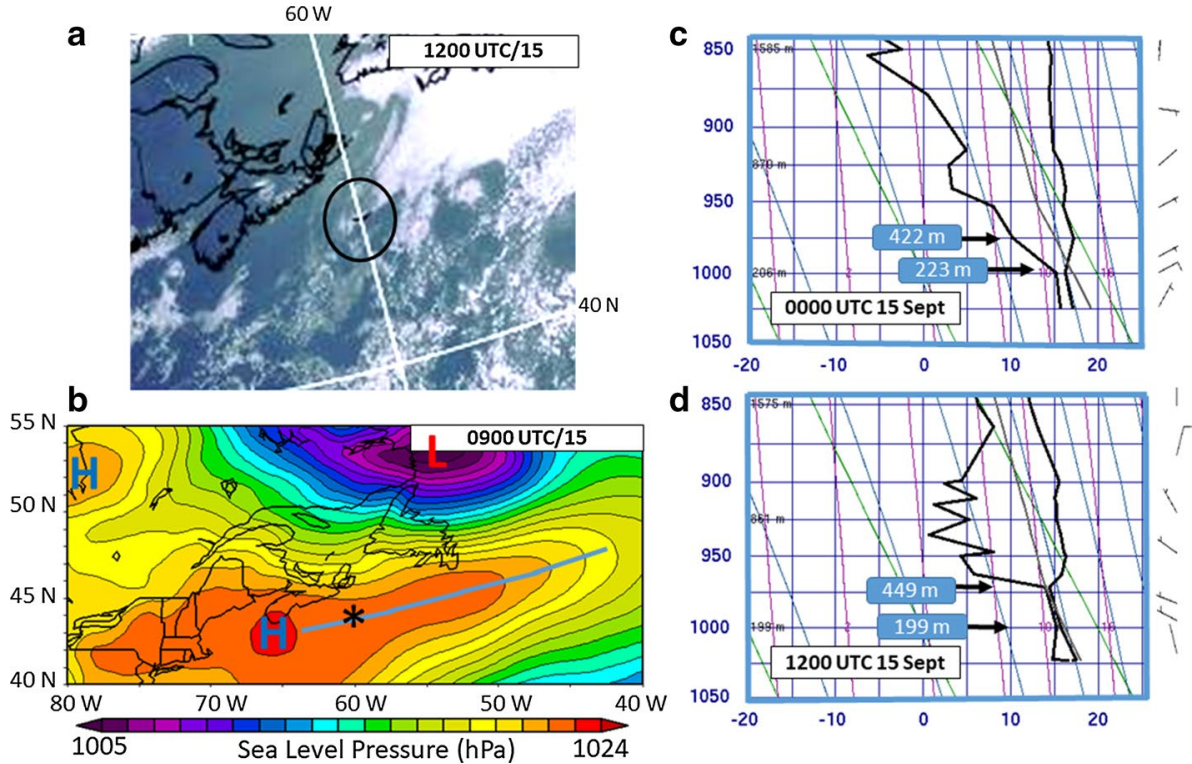

Fig. 15 Sable Island anticyclonic fog event on 0800-1100 UTC 15 September. GOES visual (a) image on 1200 UTC 15 September. NARR SLP on 0900 UTC 15 September (b). Sable Island is in circle in (a) and at the asterisk in (b), Sable Island soundings are before the fog event (c) and after the fog event (d). Satellite images from Environment Canada at https://weather.gc.ca/satellite/index_e.html. Soundings are from the University of Wyoming at http://weather.uwyo.edu/upperair/

2017, 2019). Therefore, advection itself is an unlikely direct cause of fog. Instead, synoptic activity beyond the mean SST and flow conditions are necessary to generate fog along Atlantic Canada.

\subsection{Fog Dependence on Synoptic System Paths}

Cyclonic features tend to form in the west over North America or in northern Canada and move to the east with troughs extending to the south. In addition, there is a tendency for the centres to remain at higher latitudes and move toward lower latitudes when passing Newfoundland. This explains the smaller number of cyclonic features to the south at Sable Island. On the other hand, anticyclonic features tend to form in the west and move across at lower latitudes or to extend northward from a centre at lower latitudes. The result is that there are only cyclonic features with fog in Ferryland while Sable Island has both.

\subsection{Cyclonic System Cloud-Base Lowering and Stratus Broadening as Cause of the Atlantic Canada Cyclonic Fog Events}

Aspects of the local surface and boundary-layer conditions at the onset of fog for Ferryland and Sable Island have been presented in previous sections. Here we provide a hypothesis for the cause of the cyclonic fog events. This combines the conventional cloud base lowering by a cyclonic system (Bluestein 1993) with cloud base broadening (Pilié et al. 1979; Koračin 2017). The major points follow: 
- Cyclonic systems cloud lowering (Byers 1959)

- Cyclonic systems cross the area with overcast cloud systems centred on trough axis.

- Stratus clouds are capped by an air temperature inversion and dry layer.

- As a cyclonic system centre approaches, convergence lowers stratus cloud.

- Stratus cloud bases broaden downward to surface to form fog (Gultepe et al. 2007; Tardif and Rasmussen 2008; Dupont et al. 2012).

- Cloud-top net longwave radiation upward cools cloud parcels that sink downward.

- Cloud drizzle and light rain fall into subcloud layer; this evaporates, saturates, and cools the subcloud layer.

- Stronger cyclonic systems have deeper convergence and deeper clouds that results in light rain or rain with evaporation into the subcloud layer.

- Surface layer assistance to saturation of surface layer top and cloud broadening to form fog (Koračin et al. 2014)

- Low-level convergence lifts surface air to the LCL and condensation.

- Warm air advection from the south encourages saturation at top of well mixed layer.

- Cold air advection from the north causes parcel buoyancy lifting to LCL and condensation.

- Low level convergence lifts surface air to the LCL and condensation.

- Warm air advection from the south encourages saturation at top of well mixed layer.

- Cold air advection from the north causes parcel buoyancy lifting to LCL and condensation.

\subsection{The Cause of the Atlantic Canada Anticyclonic Fog Events}

Under anticyclonic conditions, there are two causes of fog. One is under clear skies around sunrise where ground or surface longwave radiation upward cools the surface air to the dew point (Houze 1993) as well as radiation from the surface atmospheric layer (Kim and Yum 2017b). This occurred at Sable Island (Ev \#2) and Yarmouth.

The second cause is stratus broadening under a temperature inversion capped by a ridge or anticyclone. This occurred at Sable Island where a low overcast stratus layer was present. Stratus broadened downward by cloud-top radiation and assisted by factors in 4.4 .3 to form fog.

\section{Conclusions}

In this study C-FOG in-situ observations and meteorological data from several land stations together with NARR and HYSPLIT analysis were used to study marine/coastal fog occurrence conditions during September 2018. Atlantic Canada airports exposed to fog ranged from 1.1 
to $10.1 \%$ for all September observations. Fog occurrence differed widely and the timing of fog was uncorrelated over Atlantic Canada sites and between stations as close as 60 to $70 \mathrm{~km}$. This shows that fog occurrence during September was highly time- and space-dependent.

Based on the analysis, the following conclusions can be drawn:

1. The synoptic-scale structure and variations controlled the timing of fog occurrence at all Atlantic Canada stations examined.

2. Under cyclonic conditions, fog occurred with a trough axis passing overhead and nested within the clouds surrounding the trough axis.

3. Fog occurred under the central portion of an anticylone.

4. Ferryland had only cyclonic fog, while Sable Island and Yarmouth also had anticyclonic fog.

5. Surface and boundary-layer structure were presented for fog onset in Atlantic Canada. A temperature inversion capping a surface layer is a frequent occurrence with fog.

6. The fog cause for all cyclonic systems was a cyclonic system cloud-base lowering followed by cloud-base broadening downward to the surface and fog.

7. For anticyclonic fog events, it was either surface radiation or the broadening of a low stratus cloud downward to the surface to form fog.

8. No evidence was found for the cause of any fog event to be only warm-air advection at the stations examined.

\section{Appendix 1}

See Tables 6, 7, 8, 9, 10, 11, 12 .

Table 6 Statistics for meteorological surface variables at Battery during Ferryland fog events

\begin{tabular}{|c|c|c|c|c|c|c|c|c|c|c|c|c|}
\hline \multirow[t]{2}{*}{ Ev \# } & \multicolumn{3}{|c|}{$\operatorname{Ta}\left({ }^{\circ} \mathrm{C}\right)$} & \multicolumn{3}{|c|}{$W S\left(\mathrm{~m} \mathrm{~s}^{-1}\right)$} & \multicolumn{3}{|c|}{$T K E\left(\mathrm{~m}^{2} \mathrm{~s}^{-2}\right)$} & \multicolumn{3}{|c|}{ Net LW $\left(\mathrm{W} \mathrm{m}^{-2}\right)$} \\
\hline & Min & Max & Med & Min & Max & Med & Min & Max & Med & Min & Max & Med \\
\hline 1 & 11.3 & 14.0 & 12.0 & 1.1 & 4.7 & 2.1 & 0.1 & 0.6 & 0.2 & -83.2 & -34.0 & -66.9 \\
\hline 2 & 14.6 & 15.9 & 15.1 & 5.7 & 12.1 & 8.4 & 0.4 & 8.3 & 1.2 & -5.8 & -0.6 & -2.6 \\
\hline 3 & 13.6 & 14.2 & 13.9 & 3.1 & 4.6 & 3.9 & 1.3 & 2.5 & 1.9 & -20.8 & -9.5 & -12.8 \\
\hline 4 & 11.7 & 13.4 & 12.6 & 0.8 & 3.9 & 1.9 & 0.2 & 2.5 & 0.9 & -31.2 & -3.0 & -4.3 \\
\hline 5 & 10.4 & 11.5 & 10.8 & 0.4 & 2.7 & 1.8 & 0.0 & 0.6 & 0.1 & -4.9 & -3.0 & -3.5 \\
\hline 6 & 12.5 & 14.0 & 12.9 & 0.3 & 3.5 & 2.0 & 0.1 & 2.0 & 0.7 & -29.7 & 1.4 & -6.9 \\
\hline 7 & 12.3 & 13.3 & 12.5 & 0.2 & 2.3 & 1.1 & 0.0 & 0.2 & 0.0 & -14.9 & -3.6 & -7.3 \\
\hline 8 & 12.1 & 14.1 & 12.4 & 0.9 & 4.3 & 3.2 & 0.0 & 0.6 & 0.2 & -2.4 & 3.5 & 0.4 \\
\hline 9 & 12.1 & 13.9 & 12.8 & 0.1 & 5.2 & 1.1 & 0.0 & 6.1 & 0.2 & -14.8 & 5.7 & -0.7 \\
\hline 10 & 10.7 & 11.8 & 11.4 & 0.3 & 4.0 & 1.9 & 0.1 & 3.8 & 1.2 & -7.3 & 1.0 & -3.5 \\
\hline 11 & 11.2 & 15.1 & 12.3 & 0.0 & 8.2 & 2.1 & 0.0 & 5.0 & 0.2 & -45.5 & 5.9 & -1.5 \\
\hline 12 & 11.5 & 14.1 & 14.0 & 0.5 & 5.9 & 3.2 & 0.2 & 5.8 & 2.6 & -7.8 & -1.5 & -3.3 \\
\hline
\end{tabular}

$T a$ is 2-m air temperature, $W S$ is 2-m wind speed, TKE is 2-m turbulence kinetic energy,

Net LW is net longwave energy 
Table 7 September 2018 fog occurrences by hour at northern Avalon Peninsula stations of Blackhead (L), Flatrock (F) and St John's Airport (S)

\begin{tabular}{|c|c|c|c|c|c|c|c|c|c|c|c|c|c|c|c|c|c|c|c|c|c|c|c|}
\hline $\begin{array}{l}\text { Dy/ } \\
\mathrm{Hr}\end{array}$ & \begin{tabular}{l|l}
0 & 1
\end{tabular} & 2 & 3 & 4 & 5 & 6 & 7 & 8 & 9 & $\begin{array}{l}1 \\
0\end{array}$ & $\begin{array}{l}1 \\
1\end{array}$ & $\begin{array}{l}1 \\
2\end{array}$ & $\begin{array}{l}1 \\
3\end{array}$ & $\begin{array}{l}1 \\
4\end{array}$ & $\begin{array}{l}1 \\
5\end{array}$ & $\begin{array}{l}1 \\
6\end{array}$ & & $\begin{array}{l}1 \\
8\end{array}$ & & $\begin{array}{l}2 \\
0\end{array}$ & \begin{tabular}{|l|}
2 \\
1
\end{tabular} & & \begin{tabular}{|l|}
2 \\
3
\end{tabular} \\
\hline 02 & & & & & & & & & & & & & & & & & & & & & & & \\
\hline 03 & & & & & & & & & & & & & & & & & & & & & & & \\
\hline 04 & & & & & & & & & & & & & & & & & & & & & & & \\
\hline 08 & & & & & & & & & & & & & & & & & & & & & & & \\
\hline 12 & & & & & & & & & & & & & & & & & & & & & & $S$ & $\mathrm{~S}$ \\
\hline 13 & & & & & $S$ & & $\begin{array}{l}\text { S } \\
\mathrm{L} \\
\mathrm{F}\end{array}$ & $S$ & $S$ & & & & & & $S$ & & & & & $S$ & $S$ & & $\mathrm{~S}$ \\
\hline 14 & \begin{tabular}{|l|l}
$\mathrm{S}$ & $\mathrm{S}$ \\
$\mathrm{L}$ & $\mathrm{L}$ \\
$\mathrm{F}$ & $\mathrm{F}$ \\
\end{tabular} & \begin{tabular}{|l|}
$\mathrm{S}$ \\
$\mathrm{L}$ \\
$\mathrm{F}$
\end{tabular} & $\begin{array}{l}\mathrm{S} \\
\mathrm{L} \\
\mathrm{F} \\
\end{array}$ & $S$ & & $\mathrm{~S}$ & $S$ & $S$ & $S$ & $\mathrm{~S}$ & $S$ & $S$ & & & & & & & & & & & \\
\hline 15 & \begin{tabular}{|l|l} 
& $S$ \\
\end{tabular} & & & & & & & & & & & & & & & & & & & & & & \\
\hline 16 & & & & & & & & $S$ & $S$ & $S$ & $\mathrm{~S}$ & $S$ & $S$ & $S$ & $S$ & $S$ & $S$ & S & $S$ & $S$ & & & \\
\hline 17 & & & & & & & & & & & & & & & & & & & & & & & \\
\hline 27 & & & & & & & & & & & & & & & & & & & & & & & \\
\hline 28 & & & & & & & & & & & & & & $S$ & $S$ & $S$ & $S$ & $S$ & $S$ & $\begin{array}{l}\mathrm{S} \\
\mathrm{L}\end{array}$ & \begin{tabular}{|l}
$\mathrm{S}$ \\
$\mathrm{F}$
\end{tabular} & & \\
\hline 29 & \begin{tabular}{l|l}
$\mathrm{S}$ & $\mathrm{S}$ \\
& $\mathrm{L}$
\end{tabular} & $\begin{array}{ll}\mathrm{S} \\
\mathrm{L}\end{array}$ & $\begin{array}{l}\text { S } \\
\text { L } \\
\text { F }\end{array}$ & \begin{tabular}{|l|}
$S$ \\
$F$
\end{tabular} & \begin{tabular}{|l|}
$\mathrm{S}$ \\
$\mathrm{L}$ \\
\end{tabular} & \begin{tabular}{|l|}
$\mathrm{S}$ \\
$\mathrm{L}$
\end{tabular} & $S$ & $\begin{array}{l}\mathrm{S} \\
\mathrm{L}\end{array}$ & $\mathrm{F}$ & & & & & & & & & & & & & & \\
\hline 30 & & & & $S$ & & & & & & & & & & & & & & & & & & & \\
\hline
\end{tabular}

Yellow are Ferryland fog occurrences from Table 2. Hour of the day in UTC is shaded in the top row. Bold denotes near sunrise (0900 UTC) and near sunset (1900 UTC). Left column shows the day in September 2018 when fog was observed 
Table 8 September 2018 fog occurrences by hour across Sable Island and Nova Scotia

\begin{tabular}{|c|c|c|c|c|c|c|c|c|c|c|c|c|c|c|c|c|c|c|c|c|c|c|c|}
\hline $\begin{array}{l}\text { Mo } \\
\mathrm{Hr}\end{array}$ & \begin{tabular}{l|l|}
0 & 1
\end{tabular} & 2 & 3 & 4 & 5 & 6 & 7 & 8 & 9 & $\begin{array}{l}1 \\
0\end{array}$ & $\begin{array}{l}1 \\
1\end{array}$ & & $\begin{array}{l}1 \\
3 \\
\end{array}$ & $\begin{array}{l}1 \\
4 \\
\end{array}$ & $\begin{array}{l}1 \\
5\end{array}$ & $\begin{array}{l}1 \\
6\end{array}$ & $\begin{array}{l}1 \\
7\end{array}$ & $\begin{array}{l}1 \\
8\end{array}$ & & $\begin{array}{l}2 \\
0\end{array}$ & $\begin{array}{l}2 \\
1\end{array}$ & & $\begin{array}{l}2 \\
3 \\
\end{array}$ \\
\hline 02 & & & & & & & $\mathrm{Y}$ & $\mathrm{Y}$ & $\mathrm{Y}$ & $\mathrm{Y}$ & & & & & & & & & & & & & \\
\hline 03 & & & & & & & & & & & & & & & & & & & & & & & \\
\hline 04 & $Y$ & $Y$ & $Y$ & \begin{tabular}{|l|}
$Y$ \\
\end{tabular} & $\mathrm{Y}$ & $\mathrm{Y}$ & $\mathrm{Y}$ & $\mathrm{Y}$ & $\mathrm{Y}$ & $\begin{array}{l}\mathrm{Y} \\
\mathrm{H}\end{array}$ & $\begin{array}{l}\mathrm{Y} \\
\mathrm{H}\end{array}$ & $\begin{array}{ll}\mathrm{Y} \\
\mathrm{H}\end{array}$ & $\mathrm{H}$ & & & & & & & & & I & \\
\hline 08 & & & & & & & & & & & & & & & & & & & & & & & \\
\hline 12 & & $Y$ & $\mathrm{Y}$ & \begin{tabular}{|l|}
$\mathrm{Y}$ \\
\end{tabular} & \begin{tabular}{l|l} 
\\
\end{tabular} & \begin{tabular}{l|l}
$\mathrm{Y}$ \\
\end{tabular} & $\mathrm{Y}$ & $\mathrm{Y}$ & $\mathrm{Y}$ & $\mathrm{Y}$ & & & & & & & & & & & & & \\
\hline 13 & & & & & & & & & & & & & & & & & & & & & & & \\
\hline 14 & & & & & & & & & & & & & & & & & & & & & & & \\
\hline 15 & $\mathrm{~N}$ & $\mathrm{~N}$ & & & $\begin{array}{l}\mathrm{H} \\
\mathrm{N}\end{array}$ & $\begin{array}{l}\mathrm{H} \\
\mathrm{N}\end{array}$ & $\mathrm{H}$ & $\begin{array}{l}\mathrm{I} \\
\mathrm{H}\end{array}$ & $\begin{array}{l}\mathrm{I} \\
\mathrm{H}\end{array}$ & $\begin{array}{l}\mathrm{I} \\
\mathrm{H}\end{array}$ & & & & & & & & & $Y$ & $\mathrm{Y}$ & $\mathrm{Y}$ & & \\
\hline 16 & & & & & & & & & & & & & Y & $\mathrm{Y}$ & $\mathrm{Y}$ & & & & & $\mathrm{Y}$ & $\mathrm{Y}$ & $\mathrm{Y}$ & $\mathrm{Y}$ \\
\hline 17 & \begin{tabular}{|l|l|}
$Y$ & $Y$ \\
\end{tabular} & $\mathrm{Y}$ & & & I & & & & & & & & & & & & & & & & & & \\
\hline 27 & \begin{tabular}{|l|l|}
$\mathrm{Y}$ & $\mathrm{Y}$ \\
\end{tabular} & $\mathrm{Y}$ & & & & $\mathrm{Y}$ & & & & & & & & & & & & & & & & . & \\
\hline 28 & & & & & & & & & I & I & I & & & & $\mathrm{H}$ & $\mathrm{N}$ & $\mathrm{N}$ & $\mathrm{N}$ & $\begin{array}{l}\mathrm{H} \\
\mathrm{N}\end{array}$ & $\mathrm{H}$ & $\mathrm{H}$ & $\mathrm{H}$ & \\
\hline 29 & $\mathrm{H}$ & & I & $\begin{array}{l}\mathrm{I} \\
\mathrm{H}\end{array}$ & $\begin{array}{l}\mathrm{I} \\
\mathrm{H}\end{array}$ & $\begin{array}{l}\mathrm{I} \\
\mathrm{H}\end{array}$ & $\begin{array}{l}\text { I } \\
\mathrm{H}\end{array}$ & $\begin{array}{l}\mathrm{I} \\
\mathrm{H}\end{array}$ & $\begin{array}{l}\mathrm{I} \\
\mathrm{H}\end{array}$ & $\begin{array}{l}\mathrm{I} \\
\mathrm{H}\end{array}$ & $\begin{array}{l}\mathrm{I} \\
\mathrm{H}\end{array}$ & I & I & I & & I & \begin{tabular}{l|l|} 
I \\
\end{tabular} & & & & & & \\
\hline 30 & & F & & & & & & & & & & & & & & & & & & & & & \\
\hline
\end{tabular}

Yarmouth (Y) and Sable Island (I) have surface and sounding stations while Halifax (H) and Sydney (N) have only surfce. Yellow is fog at Ferryland from Table 2. Hour of day in UTC is in the top row where bold denotes near sunrise (0900 UTC) and near sunset (1900 UTC). Left column shows the days in September 2018 when fog was observed 
Table 9 Sable Island HYSPLIT 24-h back trajectory starting point direction and distance from Sable Island for September 2018

\begin{tabular}{|r|l|l|l|l|l|l|}
\hline $\begin{array}{l}\text { Ev } \\
\text { \# }\end{array}$ & $\begin{array}{l}\text { Dy/hr } \\
\text { Fog } \\
\text { start }\end{array}$ & $\begin{array}{l}\text { Dy/hr } \\
\text { Fog } \\
\text { end }\end{array}$ & $\begin{array}{l}6 \mathrm{hrs} \\
\text { before }\end{array}$ & $\begin{array}{l}\text { Fog Ev } \\
\text { Start hr }\end{array}$ & $\begin{array}{l}\text { Fog Ev } \\
\text { Last hr }\end{array}$ & $\begin{array}{l}6 \mathrm{hrs} \\
\text { ffter }\end{array}$ \\
\hline 1 & $04 / 22$ & $04 / 23$ & $\begin{array}{l}225^{\circ} \\
330 \mathrm{~km}\end{array}$ & $\begin{array}{l}243^{\circ} \\
460 \mathrm{~km}\end{array}$ & & $\begin{array}{l}267^{\circ} \\
310 \mathrm{~km}\end{array}$ \\
\hline 2 & $15 / 08$ & $15 / 11$ & $\begin{array}{l}33^{\circ} * \\
380 \mathrm{~km}\end{array}$ & $\begin{array}{l}45^{\circ} \\
250 \mathrm{~km}\end{array}$ & $\begin{array}{l}43^{\circ} \\
210 \mathrm{~km}\end{array}$ & $\begin{array}{l}61^{\circ} \\
100 \mathrm{~km}\end{array}$ \\
\hline 3 & $17 / 05$ & $17 / 06$ & $\begin{array}{l}261^{\circ} \\
480 \mathrm{~km}\end{array}$ & $\begin{array}{l}287^{\circ} \\
250 \mathrm{~km}\end{array}$ & & $\begin{array}{l}312^{\circ} * \\
190 \mathrm{~km}\end{array}$ \\
\hline 4 & $28 / 09$ & $28 / 12$ & $\begin{array}{l}220^{\circ} \\
600 \mathrm{~km}\end{array}$ & $\begin{array}{l}230^{\circ} * \\
170 \mathrm{~km}\end{array}$ & $\begin{array}{l}209^{\circ} * \\
220 \mathrm{~km}\end{array}$ & $\begin{array}{l}197^{\circ} \\
560 \mathrm{~km}\end{array}$ \\
\hline 5 & $29 / 03$ & $29 / 15$ & $\begin{array}{l}197^{\circ} \\
570 \mathrm{~km}\end{array}$ & $\begin{array}{l}204^{\circ} \\
350 \mathrm{~km}\end{array}$ & $\begin{array}{l}220^{\circ} \\
450 \mathrm{~km}\end{array}$ & $\begin{array}{l}265^{\circ} \\
270 \mathrm{~km}\end{array}$ \\
\hline 6 & $29 / 16$ & $29 / 18$ & $\begin{array}{l}217^{\circ} \\
490 \mathrm{~km}\end{array}$ & $\begin{array}{l}225^{\circ} \\
380 \mathrm{~km}\end{array}$ & $\begin{array}{l}233^{\circ} \\
350 \mathrm{~km}\end{array}$ & $\begin{array}{l}290^{\circ} \\
240 \mathrm{~km}\end{array}$ \\
\hline
\end{tabular}

See Table 3 for explanation

Table 10 Characteristics of Sable Island September 2018 fog Events

\begin{tabular}{|c|c|c|c|c|c|c|c|c|c|c|}
\hline \multirow{2}{*}{$\begin{array}{l}\text { Ev } \\
\#\end{array}$} & \multirow{2}{*}{$\begin{array}{l}\text { Day, } \\
\text { Hr } \\
\text { start } \\
\text { UTC }\end{array}$} & \multirow{2}{*}{$\begin{array}{l}\text { Day, } \\
\text { Hr } \\
\text { End } \\
\text { UTC }\end{array}$} & \multirow{2}{*}{$\begin{array}{l}\text { Light } \\
\text { Rain }\end{array}$} & \multirow{2}{*}{$\begin{array}{l}\text { Inver } \\
\text { base } \\
H T(\mathrm{~m})\end{array}$} & \multicolumn{3}{|c|}{ Satellite IR Cloud } & \multirow{2}{*}{$\begin{array}{l}\text { Satellite } \\
\text { Vis } \\
\text { Cloud }\end{array}$} & \multirow{2}{*}{$\begin{array}{l}\text { Synoptic } \\
\text { Feature } \\
\text { NARR } \\
\text { SLP }\end{array}$} & \multirow[t]{2}{*}{ Fog Type } \\
\hline & & & & & $\begin{array}{l}\text { False } \\
\text { Colour }\end{array}$ & $\begin{array}{l}\text { T } \\
\left({ }^{\circ} \mathrm{C}\right)\end{array}$ & CA? & & & \\
\hline 1 & $04 / 22$ & $04 / 23$ & B,D & $\begin{array}{l}\text { B none } \\
\text { A } 3036\end{array}$ & Dark & +10 & $\mathrm{Y}$ & $\begin{array}{l}\text { B cb, OVC } \\
\text { A SCT }\end{array}$ & $\begin{array}{l}\text { Trough } \\
\text { pass to E }\end{array}$ & CSCL, SB \\
\hline 2 & $15 / 08$ & $15 / 11$ & none & $\begin{array}{l}\text { B } 2445 \\
\text { D } 449 \\
\text { A } 338 \\
\end{array}$ & Dark & +14 & $\mathrm{~N}$ & A SCT & $\begin{array}{l}\text { High mov } \\
\text { to } \mathrm{E}\end{array}$ & Radiation \\
\hline 3 & $17 / 05$ & $17 / 06$ & none & $\begin{array}{l}\text { B none } \\
\text { A } 479 \\
\end{array}$ & Dark & +16 & $\mathrm{~N}$ & $\begin{array}{l}\text { B SCT } \\
\text { A OVC }\end{array}$ & $\begin{array}{l}\text { Weak Sfc } \\
\text { trough }\end{array}$ & $\begin{array}{l}\text { Radiation } \\
+ \text { LLC }\end{array}$ \\
\hline 4 & $28 / 09$ & $28 / 12$ & B, D & $\begin{array}{l}\text { B none } \\
\text { D } 1228 \\
\text { A none }\end{array}$ & Dark & +14 & $\mathrm{~N}$ & $\begin{array}{l}\text { D edge of } \\
\text { ovC }\end{array}$ & $\begin{array}{l}\text { Trough } \\
\text { mov to } \mathrm{E}\end{array}$ & CSCL, SB \\
\hline 5 & $29 / 03$ & $29 / 15$ & $\begin{array}{l}\mathrm{B}, \\
\mathrm{D}- \\
\text { Inter } \\
\mathrm{A}\end{array}$ & $\begin{array}{lr}\text { B } & 5 \\
\text { D } & \mathbf{6 4 9} \\
\text { A } & 282\end{array}$ & Grey & -15 & $\bar{Y}$ & $\begin{array}{l}\text { D cb, } \\
\text { OVC }\end{array}$ & $\begin{array}{l}\text { Trough } \\
\text { mov to } \mathrm{E}\end{array}$ & CSCL, SB \\
\hline 6 & $29 / 16$ & $29 / 18$ & $\mathrm{~B}, \mathrm{D}, \mathrm{A}$ & $\begin{array}{cc}\text { B } & \text { none } \\
\text { A } & 282 \\
\end{array}$ & Dark & +13 & $\mathrm{~N}$ & $\begin{array}{l}\text { B cb, OVC } \\
\text { A cb, OVC }\end{array}$ & $\begin{array}{l}\text { Trough } \\
\text { mov to } \mathrm{E}\end{array}$ & CSCL, SB \\
\hline
\end{tabular}

Relative to fog event: B (before), D (during), A (after). Inversion base HT is air temperature inversion base HT at Sable Island sounding. Under Satellite IR Cloud categories are False Colour (Dark or Grey cloud), $T$ is the cloud top temperature, and CA? is cloud layer above fog (Yes, highlighted blue or No). Under Satellite Vis (Visible) Cloud, relative to fog event is: B (before), D (during), A (after), cb denotes cloud band, OVC denotes overcast, SCT denotes scattered. Synoptic Feature NARR SLP is the synoptic feature over Sable Island during fog event based upon NARR SLP analysis. Under Fog Type: CSCL denotes cyclonic system cloud lowering, SB denotes stratus broadening, Radiation indicates upward long wave radiation from surface layer and ground, LLC indicates low level convergence. Yellow denotes cyclonic events and white denotes anticyclonic events. Light purple denotes a weak surface trough under an air temperature inversion 
Table 11 Sable Island operational surface observations from 1200 UTC 4 September 2018 to 0400 UTC 5 September 2018 that include afog event (highlighted yellow)

\begin{tabular}{|c|c|c|c|c|c|c|c|c|c|c|}
\hline $\begin{array}{l}\text { Hr:Mn } \\
\text { UTC }\end{array}$ & Dir & $\begin{array}{l}\text { Spd } \\
\left(\mathrm{m} \mathrm{s}^{-1}\right)\end{array}$ & $\begin{array}{l}\text { RH } \\
(\%)\end{array}$ & $\begin{array}{l}\text { Vis } \\
(\mathrm{km})\end{array}$ & $w x$ & Precip & $\begin{array}{l}1^{\text {st }} \text { Cloud } \\
\text { lyr Ht (m) }\end{array}$ & $\begin{array}{l}2^{\text {nd }} \text { Cloud } \\
\text { lyr Ht (m) }\end{array}$ & $\begin{array}{l}3^{\text {rd }} \text { Cloud } \\
\text { lyr Ht } \\
\text { (m) }\end{array}$ & $\begin{array}{l}\text { Sea level } \\
\text { pressure } \\
(\mathrm{hPa})\end{array}$ \\
\hline 1200 & $\mathrm{~S}$ & 4.5 & 94 & 14.48 & & & CLEAR & & & 1020.4 \\
\hline 1300 & SSW & 5.8 & 88 & 14.48 & & & $1341 \mathrm{BKN}$ & & & 1019.6 \\
\hline 1400 & SSW & 5.8 & 88 & 14.48 & & & $884 \mathrm{BKN}$ & $1158 \mathrm{BKN}$ & 1524 OVC & 1019.5 \\
\hline 1711 & WSW & 5.8 & 94 & 8.05 & Mist & & $305 \mathrm{BKN}$ & 457 OVC & & 1017.6 \\
\hline 1820 & WSW & 4.9 & 94 & 14.48 & & & 244 SCT & $396 \mathrm{BKN}$ & 640 OVC & 1017.6 \\
\hline 2030 & W & 3.6 & 94 & 14.48 & & & $244 \mathrm{BKN}$ & 427 OVC & & 1017.3 \\
\hline 2127 & W & 4.0 & 94 & 11.27 & & Lt Rain & 183 OVC & & & 1017.6 \\
\hline 2131 & W & 3.6 & 94 & 8.05 & Mist & Lt Rain & 183 oVC & & & 1017.4 \\
\hline 2149 & W & 2.7 & 100 & 4.02 & Mist & Lt Rain & 122 OVC & & & 1017.9 \\
\hline 2154 & WNW & 3.1 & 100 & 3.22 & Mist & Lt Rain & 122 OVC & & & 1017.9 \\
\hline 2200 & WNW & 2.7 & 100 & 1.61 & Mist & & $122 \mathrm{OVC}$ & & & 1018.0 \\
\hline 2203 & WNW & 2.7 & 100 & 1.21 & Mist & & $122 \mathrm{OVC}$ & & & 1018.0 \\
\hline 2217 & WNW & 2.7 & 100 & 0.61 & FOG & Lt Rain & $122 \mathrm{VV}$ & & & 1018.1 \\
\hline 2229 & WNW & 3.1 & 100 & 0.80 & FOG & Lt Rain & $152 \mathrm{VV}$ & & & 1018.0 \\
\hline 2240 & WNW & 3.1 & 100 & 1.21 & Mist & & $244 \mathrm{BKN}$ & $610 \mathrm{OVC}$ & & 1018.1 \\
\hline 2243 & WNW & 2.7 & 100 & 2.01 & Mist & & $366 \mathrm{BKN}$ & $610 \mathrm{OVC}$ & & 1018.2 \\
\hline 2250 & WNW & 3.1 & 100 & 4.82 & Mist & & 518 OVC & & & 1018.3 \\
\hline 2323 & NW & 4.0 & 100 & 6.44 & Mist & & 762 OVC & & & 1018.6 \\
\hline $\begin{array}{l}5 / \\
0100\end{array}$ & $\mathrm{~N}$ & 4.5 & 88 & 14.48 & & & 1006 OVC & & & 1019.0 \\
\hline $\begin{array}{c}5 / \\
400\end{array}$ & $\mathrm{NE}$ & 7.6 & 88 & 11.27 & & & CLEAR & & & 1020.7 \\
\hline
\end{tabular}

Variables are wind direction, wind speed, $R H$, horizontal visibility, weather (wx), precipitation, up to 3 cloud layers with base height and amount of sky covered, and sea level pressure

CLEAR means no clouds, height of cloud base is given, amount of cloud cover is SCT (scattered), BKN (broken $>50 \%$ ), OVC (overcast 100\%), VV indicates cloud base at surface, distance is the vertical visibility. Blue is the lowest sea level pressure 
Table 12 Sable Island event \# 2, surface observations for 15 September 2018

\begin{tabular}{|c|c|c|c|c|c|c|}
\hline $\begin{array}{l}\text { Hr \&Min } \\
\text { UTC }\end{array}$ & $\begin{array}{l}\text { Tair } \\
\left({ }^{\circ} \mathrm{C}\right)\end{array}$ & $\begin{array}{l}\text { Tdew } \\
\left({ }^{\circ} \mathrm{C}\right)\end{array}$ & $\begin{array}{l}\text { RH } \\
(\%)\end{array}$ & $\begin{array}{l}\text { Vis } \\
(\mathrm{km})\end{array}$ & $w x$ & $\begin{array}{l}\text { Cloud Base } \\
\text { Ht (m) }\end{array}$ \\
\hline 0600 & 16.1 & 15.0 & 94 & 12.9 & & CLR \\
\hline 0616 & 16.1 & 15.0 & 94 & 8.0 & Mist & CLR \\
\hline 0700 & 12.8 & 12.2 & 94 & 2.41 & Mist & CLR \\
\hline 0702 & 12.2 & 12.2 & 100 & 1.21 & Mist & CLR \\
\hline 0720 & 13.9 & 13.9 & 100 & 1.61 & Mist & CLR \\
\hline 0732 & 11.1 & 11.1 & 100 & 1.21 & Mist & CLR \\
\hline 0800 & 12.2 & 12.2 & 100 & 0.40 & Fog & CLR \\
\hline 0900 & 12.2 & 12.2 & 100 & 0.40 & Fog & CLR \\
\hline 1000 & 10.0 & 10.0 & 100 & 0.19 & Fog & CLR \\
\hline 1053 & 16.1 & 16.1 & 100 & 1.61 & Mist & CLR \\
\hline 1100 & 17.2 & 17.2 & 100 & 4.0 & Mist & CLR \\
\hline 1101 & 17.2 & 17.2 & 100 & 4.8 & Mist & CLR \\
\hline 1116 & 17.2 & 17.2 & 100 & 9.7 & Mist & CLR \\
\hline 1127 & 17.2 & 17.2 & 100 & 14.5 & & BKN008 \\
\hline 1148 & 17.8 & 17.2 & 94 & 14.5 & & oVC010 \\
\hline $14: 04$ & 20.0 & 16.1 & 78 & 14.5 & & BKN014 \\
\hline $15: 00$ & 20.0 & 16.1 & 78 & 14.5 & & CLR \\
\hline
\end{tabular}

Fog, highlighted in yellow, occurred between 0800 and 1053 UTC. Ceiling height is available but individual layers are not. Winds and pressure were missing

$\mathrm{wx}=$ weather, Cloud Base Ht is cloud ceiling base height

Acknowledgements This research and manuscript were funded by ONR Grant N00014-18-2472. We thank all participants of the C-FOG project. The Pacific Northwest National Laboratory is operated by Battelle Memorial Institute for the DOE under Contract DE-AC05-76RL01830.

Open Access This article is licensed under a Creative Commons Attribution 4.0 International License, which permits use, sharing, adaptation, distribution and reproduction in any medium or format, as long as you give appropriate credit to the original author(s) and the source, provide a link to the Creative Commons licence, and indicate if changes were made. The images or other third party material in this article are included in the article's Creative Commons licence, unless indicated otherwise in a credit line to the material. If material is not included in the article's Creative Commons licence and your intended use is not permitted by statutory regulation or exceeds the permitted use, you will need to obtain permission directly from the copyright holder. To view a copy of this licence, visit http://creativecommons.org/licenses/by/4.0/.

\section{References}

Arun SH, Sharma SK, Chaurasia S, Vaishnav R, Kumar R (2018) Fog/low clouds detection over the Delhi Earth Station using the ceilometer and the INSAT-3D/3DR satellite data. Int J Remote Sens 39(12):4130-4144. https://doi.org/10.1080/01431161.2018.1454624

Bluestein HB (1993) Synoptic-dynamics meteorology in midlatitudes, Vol. II, observations and theory of weather systems. Oxford University Press, Oxford

Byers HR (1959) General meteorology. McGraw Hill, New York

Dabas A, Remy S, Bergot T (2012) Use of a sodar to improve the forecast of fogs and low clouds on airports. Pure Appl Geophys 169:769-781. https://doi.org/10.1007/s00024-011-0334-y

Dorman CE, Mejia J, Koračin D, McEvoy D (2017) Worldwide marine fog occurrence and climatology. In: Koračin D, and Dorman C (eds) Marine fog: challenges and advancements in observations, 
modeling, and forecasting, Ch 2. Springer, Switzerland, pp 7-152. Doi:https://doi.org/10.1007/ 978-3-319-45229-6_2

Dorman CE, Mejia J, Koračin D, McEvoy D (2019) World marine fog analysis based on 58-years of ship observations. Int J Climatol 40:145-168. https://doi.org/10.1002/joc.6200

Dupont J-C, Haeffelin M, Protat A, Bouniol D, Boyouk N, Morille Y (2012) Stratus-fog formation and dissipation: A 6-day case study. Boundary Layer Meteorol 143:207-225. https://doi.org/10.1007/ s10546-012-9699-4

FAA (2017) Change. US Department of Transportation Federal Aviation Administration National Policy. J0 7900.5D CHG 1. 11/29/2017. pp 210. https://www.faa.gov/documentLibrary/media/Order/JO_7900. 5D.pdf

Fernando HJS, Gultepe I, Dorman C, Pardyjak E, Wang Q, Hoch SW, Richter D, Creegan E, Gaberšek S, Bullock T, Hocut C, Chang R, Alappattu D, Dimitrova R, Flagg D, Grachev A, Krishnamurthy R, Singh DK, Lozovatsky I, Nagare B, Sharma A, Wagh S, Wainwright C, Wroblewski M, Yamaguchi R, Bardoel S, Coppersmith RS, Chisholm N, Gonzalez E, Gunawardena N, Hyde O, Morrison T, Olson A, Perelet A, Perrie W, Wang S, Wauer B (2021) C-FOG: life of coastal fog. Bull Am Meteorol Soc. https://doi.org/10.1175/BAMS-D-19-0070.1

Gultepe I, Milbrandt JA (2010) Probabilistic parameterizations of visibility using observations of rain precipitation rate, relative humidity, and visibility. J Appl Meteorol Climatol 49:36-46. https://doi.org/10. 1175/2009JAMC1927.1

Gultepe I, Tardif R, Michaelides SC, Cermak J, Bott A, Bendix J, Müller MD, Pagowski M, Hansen B, Ellrod G, Jacobs W, Toth G, Cober SG (2007) Fog research: a review of past achievement and future perspectives. Pure Appl Geophys 164:1121-1159. https://doi.org/10.1007/s00024-007-0211-X

Gultepe I, Pearson G, Milbrandt JA, Hansen B, Platnick S, Taylor P, Gordon M, Oakley JP, Cober SG (2009) The fog remote sensing and modeling field project. Bull Am Meteorol Soc 90:341-359. https:// doi.org/10.1175/2008BAMS2354.1

Houze RA (1993) Cloud dynamics. Academic Press, San Diego. Doi:https://doi.org/10.1111/j.2153-3490. 1949.tb01260.x

ICAO (2007) Meteorological service for international air navigation. Annex 3 to the convention on International Civil Aviation. International Civil Aviation Organization. Sixteenth Edition. pp 187. https://www.wmo.int/pages/prog/www/ISS/Meetings/CT-MTDCF-ET-DRC_Geneva2008/Annex3_ 16ed.pdf

Kim CK, Yum SS (2017a) Turbulence in marine fog. In: Koračin D, Dorman C (eds) Marine fog: challenges and advancements in observations, modeling, and forecasting, Ch 4. Springer, Switzerland, pp 245-271. Doi:https://doi.org/10.1007/978-3-319-45229-6_4

Kim CK, Yum SS (2017b) Radiation in marine fog. In: Koračin D, and Dorman C (eds) Marine fog: challenges and advancements in observations, modeling, and forecasting, Ch 5. Springer, Switzerland, pp 273-290. Doi:https://doi.org/10.1007/978-3-319-45229-6_4

Koračin D (2017) Modeling and forecasting marine fog. In: Koračin D, and Dorman C (eds) Marine fog: challenges and advancements in observations, modeling, and forecasting, Ch 9. Springer, Switzerland, pp 425-475. Doi:https://doi.org/10.1007/978-3-319-45229-6_9

Koračin D, Dorman CE, Lewis JM, Hudson JG, Wilcox EM, Torregrosa A (2014) Marine fog: a review. Atmos Res 143:142-175. https://doi.org/10.1016/j.atmosres.2013.12.012

Lewis JM, Koračin D, Redmond KT (2004) Sea fog research in the United Kingdom and United States: a historical essay including outlook. Bull Am Meteorol Soc 85:395-408. https://doi.org/10.1175/ BAMS-85-3-395

Li P, Wang G, Fu G, Lu C (2016) On spatiotemporal characteristics of sea fog occurrence over the Northern Atlantic from 1909 to 2008. J Ocean Univ China 15:958-966. https://doi.org/10.1007/ s11802-016-3077-7

Mesinger F, DiMego G, Kalnay E, Mitchell K, Shafran PC, Ebisuzaki W, Jović D, Woollen J, Rogers E, Berbery EH, Ek MB, Fan Y, Grumbine R, Higgins W, Li H, Lin Y, Manikin G, Parrish D, Shi W (2006) North American regional reanalysis. Bull Am Meteorol Soc 87:343-360. https://doi.org/10. 1175/BAMS-87-3-343

Palmén E (1969) Atmospheric circulation systems. Their structure and physical interpretation. In: Newton CW (ed) International geophysics, Vol 13. Academic Press, New York

Pilié RJ, Mack EJ, Rogers CW, Katz U, Kocmond WC (1979) The formation of marine fog and the development of fog-stratus systems along the California coast. J Appl Meteorol 18:1275-1286. https://doi.org/ 10.1175/1520-0450(1979)018\%3c1275:TFOMFA\%3e2.0.CO;2

Reitan CH (1974) Frequencies of cyclones and cyclogenesis for North America, 1951-1970. Mon Weather Rev 102(12):861-868. https://doi.org/10.1175/1520-0493(1974)102\%3c0861:FOCACF\%3e2.0.CO;2 
Reynolds RW, Rayner NA, Smith TM, Stokes DC, Wang W (2002) An improved in situ and satellite SST analysis for climate. J Clim 15:1609-1625. https://doi.org/10.1175/1520-0442(2002)015\%3c1609:AII$\mathrm{SAS} \% 3 \mathrm{e} 2.0 . \mathrm{CO} ; 2$

Rolph G, Stein A, Stunder B (2017) Real-time environmental applications and display system: ready. Environ Modell Softw 95:210-228. https://doi.org/10.1016/j.envsoft.2017.06.025

Stein AF, Draxler RR, Rolph GD, Stunder BJB, Cohen MD, Ngan F (2015) NOAA's HYSPLIT atmospheric transport and dispersion modeling system. Bull Am Meteorol Soc 96:2059-2077. https://doi.org/10. 1175/BAMS-D-14-00110.1

Tardif R (2017) Precipitation and fog. In: Koračin D, Dorman C (eds) Marine fog: challenges and advancements in observations, modeling, and forecasting, Ch 8. Springer, Switzerland, pp 395-423. Doi:https://doi.org/10.1007/978-3-319-45229-6_8

Taylor GI (1917) The formation of fog and mist. Q J R Meteorol Soc 43:241-268. https://doi.org/10.1002/ qj.49704318302

Tomczak M, Godfrey JS (2020) Regional oceanography: an introduction. Daya Publishing House, Delhi

Wang BH (1985) Sea fog. China Ocean Press, Beijing

Wang XL (2006) Climatology and trends in some adverse and fair weather conditions in Canada, 19532004. J Geophys Res. https://doi.org/10.1029/2005JD006155

Zishka KM, Smith PJ (1980) The climatology of cyclones and anticyclones of North America and surrounding ocean environs for January and July, 1950-77. Mon Weather Rev 108:387-401. https://doi.org/10. 1175/1520-0493(1980)108\%3c0387:TCOCAA\%3e2.0.CO;2

Publisher's Note Springer Nature remains neutral with regard to jurisdictional claims in published maps and institutional affiliations.

\section{Authors and Affiliations}

\section{Clive E. Dorman ${ }^{1,2}$ (D) Sebastian W. Hoch ${ }^{3}$ Ismail Gultepe ${ }^{4,5,6} \cdot$ Qing Wang ${ }^{7,8}$. Ryan T. Yamaguchi ${ }^{7}$ H. J. S. Fernando ${ }^{6} \cdot$ Raghavendra Krishnamurthy $^{6,9}$}

1 Integrative Oceanography Division, Scripps Institution of Oceanography, University of California, San Diego, La Jolla, CA 92093-0209, USA

2 Department of Geological Sciences, San Diego State University, San Diego, CA 92182-1020, USA

3 Department of Atmospheric Sciences, University of Utah, Salt Lake City, UT 84112-0110, USA

4 Meteorological Research Division (MRD), Environment and Climate Change of Canada (ECCC), Toronto, ON M3H-5T4, Canada

5 Faculty of Engineering and Applied Science, Ontario Technical University (UOIT), Oshawa, ON L1G-0C5, Canada

6 Department of Civil and Environmental Engineering and Earth Sciences, and Department of Aerospace and Mechanical Engineering, University of Notre Dame, Notre Dame, IN 46556, USA

7 Department of Meteorology, Naval Postgraduate School, Monterey, CA 93943, USA

8 Moss Landing Marine Laboratory, Moss Landing, CA 95039, USA

$9 \quad$ Pacific Northwest National Laboratory, Richland, WA 99352, USA 